\title{
Ash leachates from some recent eruptions of Mount Etna (Italy) and Popocatépetl (Mexico) volcanoes and their impact on amphibian living freshwater organisms
}

\author{
M. D'Addabbo ${ }^{1}$, R. Sulpizio ${ }^{1,2}$, M. Guidi ${ }^{3}$, G. Capitani ${ }^{4}$, P. Mantecca ${ }^{4}$, and G. Zanchetta $^{5}$ \\ ${ }^{1}$ Dipartimento di Scienze della Terra e Geoambientali, via Orabona 4, 70125 Bari, Italy \\ ${ }^{2}$ IDPA-CNR, via M. Bianco 9, Milan, Italy \\ ${ }^{3}$ IGG-CNR, via Moruzzi 1, Pisa, Italy \\ ${ }^{4}$ Dipartimento di Scienze dell' Ambiente e del Territorio e di Scienze della Terra, Piazza della Scienza 1, 20126 Milan, Italy \\ ${ }^{5}$ Dipartimento di Scienze della Terra, via S. Maria 53, 56126 Pisa, Italy
}

Correspondence to: R. Sulpizio (roberto.sulpizio@uniba.it)

Received: 17 July 2015 - Published in Biogeosciences Discuss.: 17 August 2015

Revised: 13 November 2015 - Accepted: 20 November 2015 - Published: 8 December 2015

\begin{abstract}
Leaching experiments were carried out on fresh ash samples from Popocatépetl 2012, Etna 2011, and Etna 2012 eruptions, in order to investigate the release of compounds in both double-deionized and lake (Lake Ohrid, FYR of Macedonia) waters. The experiments were carried out using different grain sizes and variable stirring times (from $30 \mathrm{~min}$ to 7 days). Results were discussed in the light of changing $\mathrm{pH}$ and release of compounds for the different leachates. In particular, Etna samples induced alkalinization, and Popocatépetl samples induced acidification of the corresponding leachates. The release of different elements does not show correlation with the stirring time, with the measured maximum concentrations reached in the first hours of washing. General inverse correlation with grain size was observed only for $\mathrm{Na}^{+}, \mathrm{K}^{+}, \mathrm{Cl}^{-}, \mathrm{Ca}^{2+}, \mathrm{Mg}^{2+}, \mathrm{SO}_{4}^{2-}$, and $\mathrm{Mn}^{2+}$, while the other analysed elements show a complex, scattering relationship with grain size.

Geochemical modelling highlights leachates' saturation only for $\mathrm{F}$ and $\mathrm{Si}$, with Popocatépetl samples sometimes showing saturation in Fe.

The analysed leachates are classified as undrinkable for humans on the basis of European laws, due to excess in $\mathrm{F}^{-}$, $\mathrm{Mn}^{2+}, \mathrm{Fe}$, and $\mathrm{SO}_{4}^{2-}$ (the latter only for Popocatépetl samples).
\end{abstract}

Finally, the Etna 2012 and Popocatépetl leachates were used for toxicity experiments on living biota (Xenopus laevis). They are mildly toxic, and no significant differences ex- ist between the toxic profiles of the two leachates. In particular, no significant embryo mortality was observed; while even at high dilutions, the leachates produced more than $20 \%$ of malformed larvae.

\section{Introduction}

Volcanic ash is the most widely distributed product of explosive volcanic eruptions, and areas hundreds of kilometres from an erupting volcano could receive ash falls (Ruggieri et al., 2010; Sulpizio et al., 2014). Even minor quantities of deposited ash represent a major hazard for the modern technical society and the environment (Blong, 1984; Johnston and Houghton, 2000). Deposition of fresh volcanic ash can disrupt power lines (Wardman et al., 2012), transport networks, and water supplies (Martin et al., 2009; Wilson et al., 2012), or induce $\mathrm{pH}$ variations and pollution in soils and surface water, which have a serious impact on vegetation, animals, and people (Ayris and Delmelle, 2012).

In particular, deposition of volcanic ash into aqueous environments leads to dissolution of adsorbed salts and aerosols, increasing the bioavailability of both key nutrients and pollutants. This is because acids, metal salts, and adsorbed gases on tephra (airborne volcanic particulate matter) surfaces are highly soluble, dissolving rapidly on contact with water (Frogner et al., 2001). These soluble surface accumula- 
tions have been termed "ash leachates" by previous investigators (e.g. Witham et al., 2005) and we use this term hereafter. Ash leachate chemistry and volume can vary considerably, depending on different gas solubility and degree of magma degassing prior to or during the eruption (Oppenheimer et al., 2003). These processes are largely governed by the composition of the source magma (Armienta et al., 2002), but additional factors are also important, like the tephra particle size, the gas/ash ratio, and the time the ash remains in the volcanic cloud (Óskarsson, 1980; Witham et al., 2005).

Over 55 soluble components have been reported in volcanic ash leachates, with the anions $\mathrm{Cl}^{-}, \mathrm{SO}_{4}^{2-}$, and $\mathrm{F}^{-}$, and the cations $\mathrm{Ca}^{2+}, \mathrm{Na}^{+}$, and $\mathrm{Mg}^{2+}$ generally occurring at the highest concentrations (Witham et al., 2005).

The rapid release of nutrients and metals following the mixing of unhydrated ash or aerosols with surface waters has been the focus of field studies (Gíslason et al., 2002; Uematsu, 2004; Flaathen and Gìslason, 2007; Jones and Gìslason, 2008) and experimental studies (Frogner et al., 2001; Duggen et al., 2007). The effects of ash fall on natural waters and water supplies have focused mainly on the consequences of increased levels of turbidity (ash suspended in water), acidity, and fluoride content (Collins, 1978; Óskarsson, 1980; Weniger and Blaser, 1983; Cronin and Sharp, 2002; Stewart et al., 2006; Smithsonian Institution, 1997). On the other hand, contamination of drinking water is a major concern for public health, due to the potential for outbreaks of waterborne infectious diseases due to the inhibition of disinfection at high levels of turbidity. Moreover, elevated concentrations of fluoride increase the risks of dental and skeletal fluorosis (Stewart et al., 2006).

Impacts of ash on environment have been reported subsequently to a number of historic eruptions. During the 17831784 eruption of Laki (Iceland) $50 \%$ of the livestock in Iceland perished, many probably as a result of fluorine poisoning (Thorarinsson, 1969; Grattan and Charman, 1994; Steingrímsson and Kunz, 1998). After the 1947-1948 eruption of Hekla in Iceland, some rivers and streams showed temporarily elevated fluoride concentrations (up to $9.5 \mathrm{mg} \mathrm{L}^{-1}$; Stefánsson and Sigurjónsson, 1957). The ash from the $1969 \mathrm{Ru}-$ apehu eruptions contaminated water supplies, with $\mathrm{pH}$ values ranging from 4.4 to 6.0 (Collins, 1978; Stewart et al., 2006). Similar $\mathrm{pH}$ values in receiving waters following volcanic ash deposition have been reported in many other studies (Wilcox and Coats, 1959; Cronin and Sharp, 2002; Smithsonian Institution, 1997). The ash from the $2012 \mathrm{Mt}$. Tongariro eruption (New Zealand) had higher concentrations of $\mathrm{F}^{-}, \mathrm{Al}^{3+}$, $\mathrm{Ca}^{2+}$, and $\mathrm{SO}_{4}^{2-}$ and generated significant agricultural problems, including livestock deaths (Cronin et al., 2014).

Several recent eruptions have had high quantities of fluorine adsorbed on the tephra, including Hekla, Iceland, in 1970, 1991, and 2000 (Frogner et al., 2001; Gudmundsson and Oskarsson, 1992; Thorarinsson and Sigvaldason, 1972); Lonquimay, Chile, in 1989-1900 (Araya et al., 1990, 1993); and Ruapehu, New Zealand, in 1995-1996 (Shanks, 1997; Cronin et al., 2003).

Other than fluoride release and acidity, little attention has been paid to the contamination of water supplies by other soluble components of ash. There are some reports of elevated levels of iron, sulfate, and chloride (Smithsonian Institution, 1997, 2000; Cronin and Sharp, 2002; Baxter and Ancia, 2002) but little or no discussion of their environmental impact. Evidence for phytoplankton blooms as a result of volcanogenic sedimentation have been observed in lakes (Smith and White, 1985) and in oceans, based on preliminary satellite data (Duggen et al., 2007). Bio-incubation experiments have shown diatoms utilizing nutrients from volcanic ash (Duggen et al., 2007). Mesoscale iron enrichment experiments have shown that $\mathrm{Fe}$ addition to low chlorophyll ocean waters can instigate elevated marine primary productivity (Boyd et al., 2000).

In order to supply new data useful for understanding the behaviour of release of water contaminants from fresh volcanic ash and their impact on water supplies and living organisms, we collected ash deposits from two recent eruptions of Mount Etna (Italy, August 2011 and April 2012) and from the May 2012 eruption of Popocatépetl volcano (Mexico). The collected volcanic ash was washed using two different types of water (double deionized and natural lake water), and the released compounds analysed for major and trace elements. The results were discussed in the light of international (European drinking water directive, 98/83/EC) drinkable limits for public waters.

Since the decline of amphibian populations has been demonstrated to be a major consequence of the anthropic and naturally occurring environmental changes (Hayes et al., 2010), the ash leachates were also tested for toxicity using the amphibian Xenopus laevis as a biological model. The bioassays were performed using the standardized Frog Embryo Teratogenesis Assay - Xenopus (FETAX) (ASTM E1439-12, 1998), already successfully applied to ecotoxicological investigations for testing single compounds and mixtures (Dawson, 1991; Bacchetta et al., 2008), municipal sludge (Chenon et al., 2003), and material and sediment extracts (Mantecca et al., 2007; Fort et al., 2001).

\section{Materials and methods}

\subsection{Bulk rock, glass composition, and sublimates}

The samples used in the experiments are fresh volcanic ash from the 12 August 2011 and 24 April 2012 eruptions of Mount Etna (southern Italy), and the eruption of May 2012 of Popocatépetl (Mexico). The samples were placed in polyethylene bags and carried to the laboratory for dry sieving between $63 \mu \mathrm{m}$ and $1 \mathrm{~mm}$ at $1 \varphi$ interval $\left(\varphi=\log _{2} d\right.$, where $d$ is the particle diameter). 
The composition of bulk ash samples was obtained by XRF using a Philips PW1480/10 automatic spectrometer $(\mathrm{Cr}$ anticathode for major and minor elements, $\mathrm{Rh}$ anticathode for $\mathrm{Rb}, \mathrm{Sr}, \mathrm{Y}, \mathrm{Zr}, \mathrm{Nb}$, and $\mathrm{W}$ anticathode for $\mathrm{Ce}, \mathrm{La}, \mathrm{Ba}$, $\mathrm{Ni}, \mathrm{Cr}$, and V) at Dipartimento di Scienze della Terra e Geoambientali (University of Bari) following the analytical techniques outlined by Franzini et al. (1975) and Leoni and Saitta (1976). Energy dispersion system (EDS) analyses were performed on glass and mineral phases of the different tephra samples embedded in epoxy resin, polished and coated with carbon at the Dipartimento di Scienze della Terra (University of Pisa), using an EDAX-DX microanalyser mounted on a Philips scanning electron microscope (SEM) 515 (operating conditions: $20 \mathrm{kV}$ acceleration voltage, $100 \mathrm{~s}$ live time counting, $10^{-9}$ a beam current; atomic number of the element (Z), absorbance (A), and fluorescence (F) ZAF correction). Instrument calibration and performance are described in Marianelli and Sbrana (1998). Back-scattered electrons (BSE) SEM images of sublimate compounds on ash surfaces were obtained with a 50XVP LEO SEM at the Dipartimento di Scienze della Terra e Geoambientali (University of Bari).

\subsection{Leachates analyses}

Two types of water were used for washing the ash samples: double deionized (mQ) water, and Lake Ohrid (Macedonia) water. Lake water was filtered immediately after sampling through $0.2 \mu \mathrm{m}$ Millipore membranes (cellulose acetate).

Leaching experiments were performed on $2 \mathrm{~g}$ sieved ash, which was added in previously washed plastic cuvettes containing $20 \mathrm{~mL} \mathrm{mQ}$ water $\left(18.2 \mathrm{M} \Omega \mathrm{cm}^{-1}\right)$ or lake water. The washing was performed at ambient temperature $\left(25-28^{\circ} \mathrm{C}\right)$ on a table shaker (stirring at $150 \mathrm{rpm}$ ), in order to ensure efficient mixing of the leaching suspension.

The stirring duration varied from $30 \mathrm{~min}$ to 7 days (intermediate steps at some hours, 1 day, and 5 days) depending on the amount of available ash. The grain sizes that were used varied from $1 \mathrm{~mm}$ to $0.063 \mathrm{~mm}$.

The samples were centrifuged for $10 \mathrm{~min}$ at $3500 \mathrm{rpm}$ and filtrated immediately.

The $\mathrm{pH}$ of the leachates was measured using a glass electrode (ORION), sensitive to the activity of $\mathrm{H}^{+}$ions, coupled with an Ion Analyser EA920 (instrumental error less than 0.5 $\mathrm{pH}$ units, reproducibility of the data better than $5 \%$ ).

The ammonia and ammonium concentration was measured using a specific electrode (ORION) coupled with an Ion Analyser EA920, following the procedure recommended in Clesceri et al. (1998). The additions method (Harvey, 2000) was used for this analysis. $\mathrm{NH}_{4} \mathrm{Cl}$ standards were prepared starting from $1000 \gamma \mathrm{mL}^{-1}$, obtaining the standard $\mathrm{NH}_{4} \mathrm{Cl} 100 \gamma \mathrm{mL}^{-1}$ and the standard $\mathrm{NH}_{4} \mathrm{Cl} 10 \gamma \mathrm{mL}^{-1}$ (reproducibility of the data better than $10 \%$ ). The analysis provides the sum of $\mathrm{NH}_{3}$ and $\mathrm{NH}_{4}^{+}$in the solution, whose parti- tion (Table 1) is pH-dependent:

$\alpha=\frac{\left[\mathrm{NH}_{3}\right]}{\left[\mathrm{NH}_{4}^{+}\right]}=\frac{K}{10^{-\mathrm{pH}}} \frac{\gamma_{\mathrm{NH} 4}^{+}}{\gamma_{\mathrm{NH}_{3}}}$,

where the concentrations of the two chemical species are in square brackets, $\gamma$ indicates the activity coefficients, and $K$ is the thermodynamic constant $(\mathrm{pK}=9.24) . \mathrm{NH}_{3}$ and $\mathrm{NH}_{4}^{+}$ concentrations can be therefore calculated using

$\left[\mathrm{NH}_{4}^{+}+\right]=\frac{\mathrm{C}}{\alpha+1} ;\left[\mathrm{NH}_{3}\right]=\frac{\mathrm{C} \alpha}{\alpha+1}$.

Composition of major elements $\left(\mathrm{Na}^{+}, \mathrm{K}^{+}, \mathrm{Ca}^{2+}, \mathrm{Mg}^{2+}\right.$, $\mathrm{Cl}^{-}, \mathrm{SO}_{4}^{2-}, \mathrm{F}^{-}$) of ash leachates was determined by ion chromatography (IC). Trace elements were measured using an inductively coupled plasma optical emission spectrometry (ICP-OES) using an Optimal 2000 DV instrument. Operating conditions were as follows: power $1400 \mathrm{~W}$, plasma argon flow rate $15 \mathrm{~L} \mathrm{~min}-1$, nebulizer argon flow rate $0.55 \mathrm{~L} \mathrm{~min}^{-1}$, and sample flow rate $2 \mathrm{~mL} \mathrm{~min}^{-1}$.

A Dionex model 100 with AS4A ION CAP anion exchange column and chemical suppression of eluent conductivity technique was used to analyse anions $\left(\mathrm{F}^{-}, \mathrm{Cl}^{-}, \mathrm{SO}_{4}^{2}\right)$, while the analysis of cations $\left(\mathrm{Na}^{+}, \mathrm{K}^{+}, \mathrm{Ca}^{2+}, \mathrm{Mg}^{2+}\right)$, was performed using a Dionex model 600 with ION PAC CS12A and chemical suppression of eluent conductivity technique. The reproducibility of the data is better than $4 \%$ for both anions and cations. The calibration curves for each element were prepared using calibration standards, and repeated for the analysed elements every 10 samples. The samples were diluted by a factor of $1: 10$.

The calibration curve for trace elements was carried out using calibration standards prepared diluting a stock solution (1000 ppm) with deionized water. Recovery experiments were carried out by adding measured volumes of aqueous standard solutions of each metal to measured volumes of an acidified deionized water sample. Calibration curves were repeated for the analysed elements every 14 samples. Reproducibility of the data is better than $3 \%$.

\subsection{FETAX test}

Ash leachates from Etna 2012 and Popocatépetl in mQ water were used for laboratory analysis on living biota. The methodology of the FETAX Assay and the experimental design imply that adult Xenopus laevis were maintained in aquaria with de-chlorinated tap water at a $22^{\circ} \mathrm{C} \pm 2$ alternating $12 \mathrm{~h}$ light/dark cycle and fed a semi-synthetic diet (Mucedola S.r.l., Settimo Milanese, Italy) three times a week.

For a single bioassay, three males and three females received a 300 IU human chorionic gonadotrophin (HCG) via injection in the dorsal lymph sac to induce mating. Breeding tanks were filled with FETAX solution (composition in $\mathrm{mg} \mathrm{L}^{-1}$ was $625 \mathrm{NaCl}, 96 \mathrm{NaHCO}_{3}, 30 \mathrm{KCl}, 15 \mathrm{CaCl}_{2}, 60$ $\mathrm{CaSO}_{4}-2 \mathrm{H}_{2} \mathrm{O}$, and $\left.70 \mathrm{MgSO}_{4} ; \mathrm{pH} 7.5-8.5\right)$ and aerated before introducing a couple. Amplexus normally ensued within 


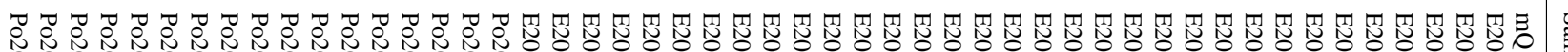

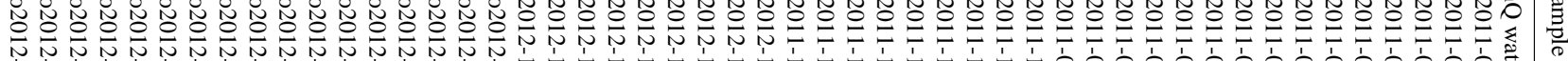

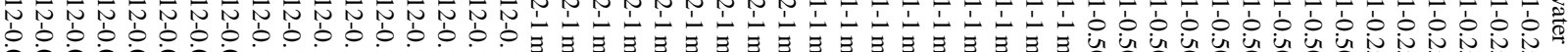

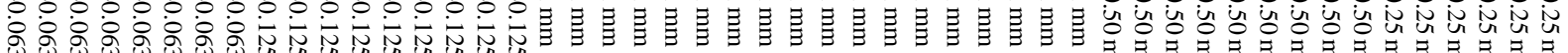

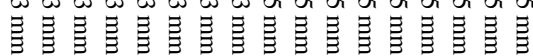

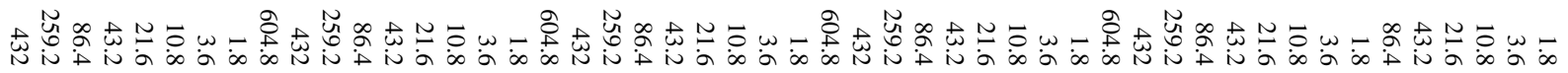

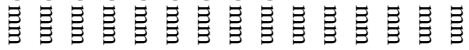

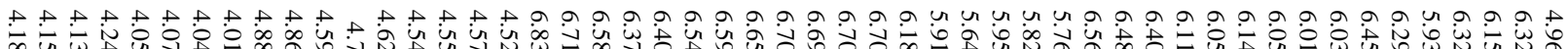

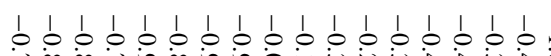

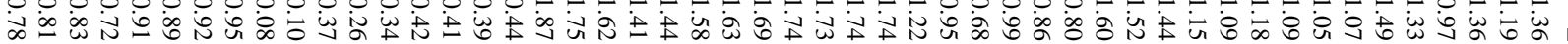

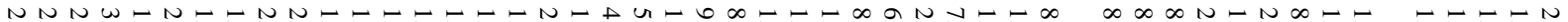

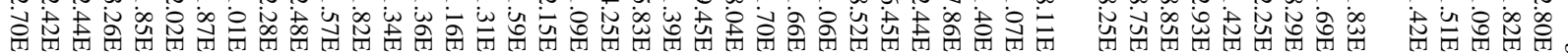

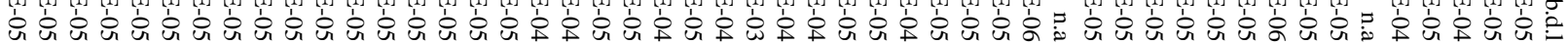

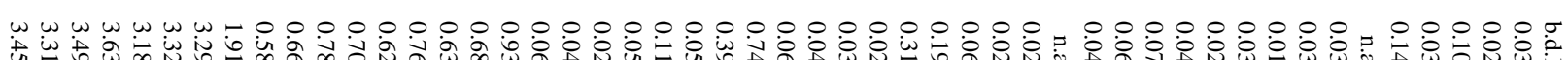

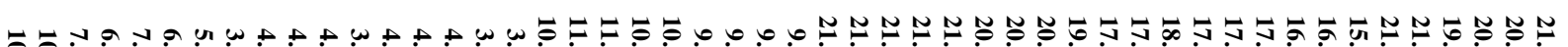

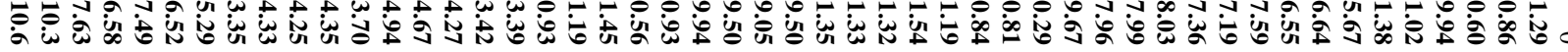

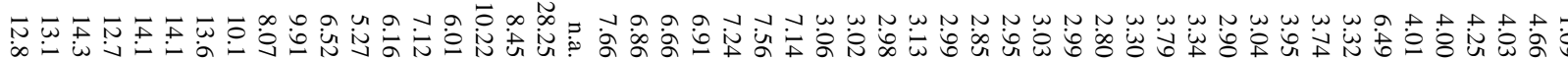

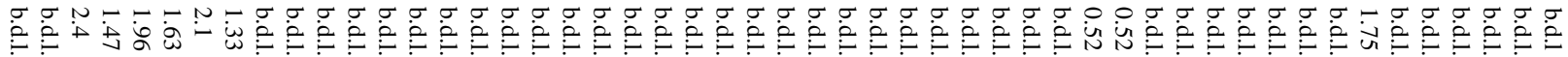

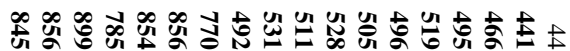

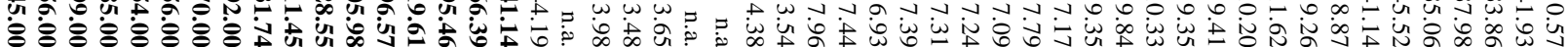
й

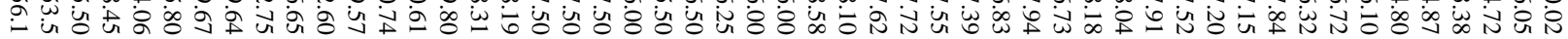

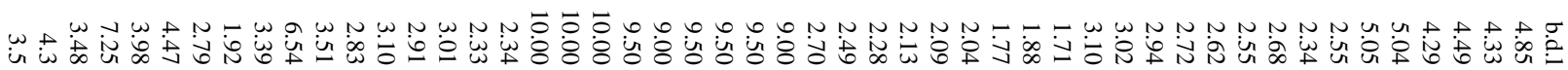
จㅇำ -

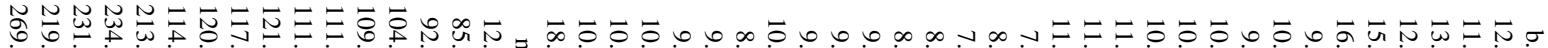
공

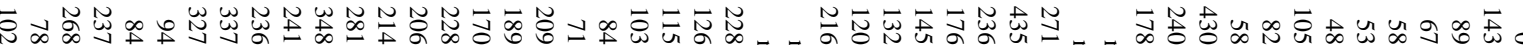
户

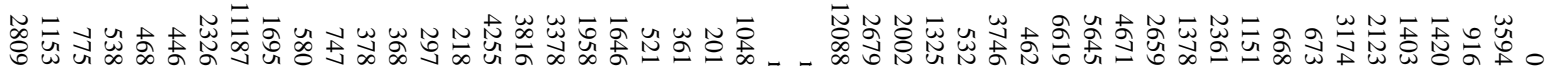

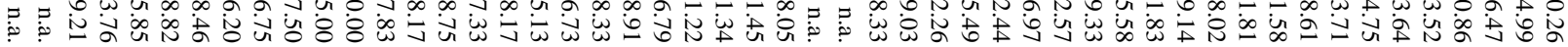

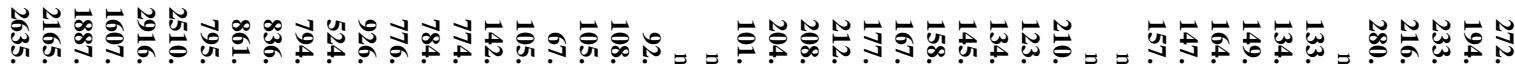

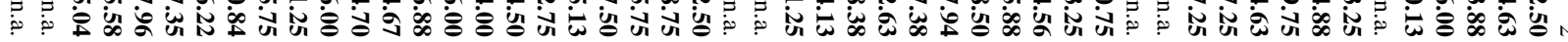

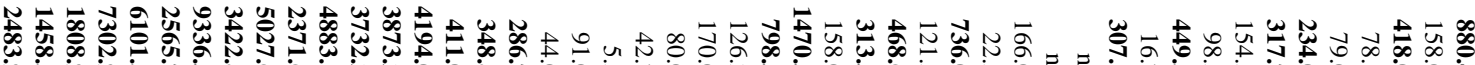
户

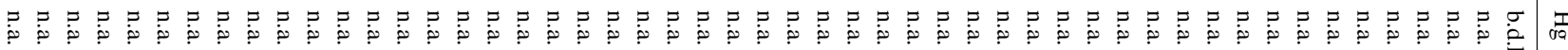

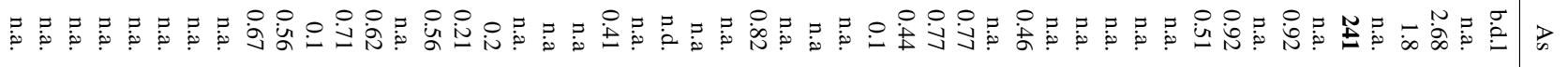




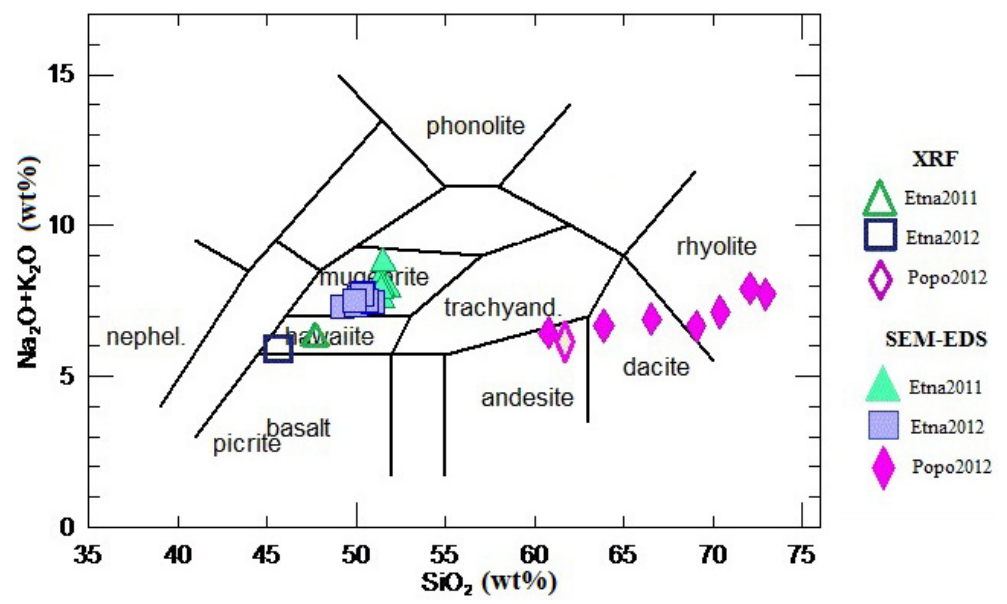

Figure 1. Total alkali vs. silica (TAS) diagram for bulk rock and glass analyses of Etna 2011, Etna 2012, and Popocatépetl samples.

2 to $6 \mathrm{~h}$ and the deposition of fertilized eggs took place from 9 to $12 \mathrm{~h}$ later. After breeding, the adults were removed and the embryos were collected in $60 \mathrm{~mm}$ glass Petri dishes. Abnormally cleaved embryos and necrotic eggs were removed.

Normally cleaved embryos at mid-blastula stage (stage 8), $5 \mathrm{~h}$ post-fertilization (hpf) (Niewkoop and Faber, 1956) were selected for testing and then placed in $6 \mathrm{~cm}$ glass Petri dishes, each Petri containing $10 \mathrm{~mL}$ of control or test solutions. Test solutions were generated by diluting the Etna and Popocatépetl mQ leachates in FETAX solution, to obtain the final dilutions of $1: 5,1: 10,1: 50$, and $1: 100$.

For each female the plates were duplicated or triplicated when well-cleaved embryos were available. All the Petri were incubated in a thermostatic chamber at $23 \pm 0.5^{\circ} \mathrm{C}$ until the end of the test, $96 \mathrm{hpf}$. At this moment mortality and malformation data were generated as endpoints of the assay.

The number of dead embryos vs. their total number at the beginning of the test led to the mortality percentages and the number of malformed larvae vs. the total number of surviving ones gave the malformed larva percentages.

\section{Results}

\subsection{Ash composition and surface analysis}

The bulk rock composition, the glass/mineral phases, and the sublimated composition of the collected samples were analysed by XRF and SEM-EDS techniques. The bulk composition (Supplement Table S1) of Etna samples are plotted in the hawaiite field, while the Popocatépetl sample can be classified as andesite (Fig. 1).

The EDS analyses of Etna samples on glass (Table S2) show an almost homogeneous, more evolved composition (mugearites) with respect to the parental bulk analyses (Fig. 1). The Popocatépetl glass analyses gather on a trend from andesite to rhyolite (Fig. 1).
As from SEM-BSE images of polished samples, both Etna and Popocatépetl samples are porphyritic, with phenocrystals and groundmass microcrystals (Fig. 2). The mineralogical assemblage of Etna samples comprises Mg-rich olivine clinopyroxene, plagioclase, and oxides (Table S3). In particular, the clinopyroxene is diopside in both 2011 and 2012 samples (Fig. 3a). Plagioclase in the sample from the 2011 eruption has an almost homogeneous bytownite composition (Fig. 3b), while the sample from the 2012 eruption shows a compositional range between bytownite and labradorite (Fig. 3b).

The mineralogical assemblage of Popocatépetl comprises ortho- and clinopyroxenes, plagioclase, and oxides (Supplement Table S3). Orthopyroxenes are enstatite (Fig. 3a), while clinopyroxenes are augite (Fig. 3a). Plagioclase shows a small compositional range within the labradorite field (Fig. 3b).

SEM-BSE images are shown in Fig. 4. The sublimates recognized on ash surfaces of Etna 2011 (Fig. 4a and b) and Etna 2012 samples are mainly sodium chloride $(\mathrm{NaCl}$, halite) and calcium di-fluoride $\left(\mathrm{CaF}_{2}\right.$, fluorite) (Fig. $4 \mathrm{c}$ and d). Popocatépetl samples show abundant sublimate compounds, including sodium chloride, calcium sulfate (gypsum, $\mathrm{CaSO}_{4} \cdot 2 \mathrm{H}_{2} \mathrm{O}$ or anhydrite $\mathrm{CaSO}_{4}$ ), iron sulfide (pyrite $\mathrm{FeS}_{2}$ or greigite $\mathrm{Fe}^{\mathrm{II}} \mathrm{Fe}_{2}^{\mathrm{III}} \mathrm{S}_{4}$ ), and native $\mathrm{S}$ (Fig. 4 e and f).

\subsection{Ash leachates}

Leaching experiments (Tables 1 and 2) were performed using $2 \mathrm{~g}$ of sieved ash, which was added with $20 \mathrm{~mL}$ of $\mathrm{mQ}$ or lake water.

\subsection{1 pH variation}

The $\mathrm{pH}$ of ash leachates ranges from ca. 4 (Popocatépetl $63 \mu \mathrm{m}$ ) to ca. 6.50 (Etna $20110.5 \mathrm{~mm}$; Fig. 5). The pH variation is very limited when plotted vs. different stirring times 

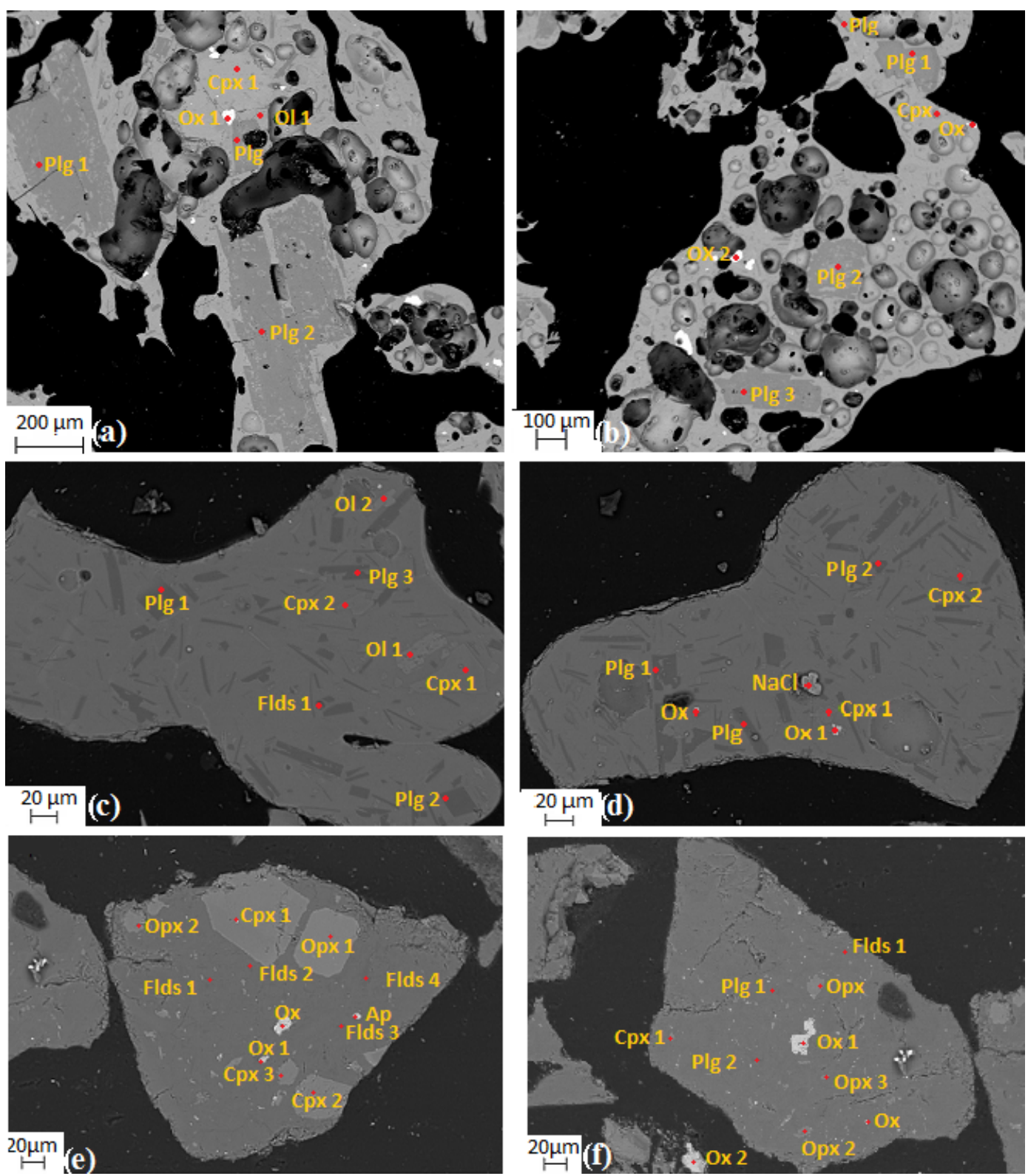

Figure 2. BSE-SEM images of polished particles from Etna 2011 (a, b), Etna 2012 (c, d), and Popocatépetl samples (e, f). Cpx represents clinopyroxene; Opx orthopyroxene; Ox oxide; Plg plagioclase; Ol olivine; Ap apatite; and Flds feldspar.

within each sample, for both $\mathrm{mQ}$ and lake waters (Fig. 5). This indicates that most of the $\mathrm{pH}$ variations are acquired within the first 30 min of stirring.

As a general behaviour, the Popocatépetl leachates induce acidification in the solution, diminishing the $\mathrm{pH}$ values of $0.24 \pm 0.18$ (lake water; Table 2) and $0.57 \pm 0.30$ (mQ water; Table 1) pH units (Fig. 5). The Etna samples show opposite behaviour, i.e. they induce slight $(0.34 \pm 0.11 \mathrm{pH}$ units for lake water; Table 2$)$ to moderate $(1.34 \pm 0.2 \mathrm{pH}$ units for $\mathrm{mQ}$ water; Table 1) alkalization (Fig. 5). In both cases the buffering effect of lake water on $\mathrm{pH}$ variations is evident, which also shows a slight dependence on decreasing grain size of leached ash (Fig. 5).

\subsection{2 $\mathrm{NH}_{3}-\mathrm{NH}_{4}^{+}$concentration}

The analysed samples show a very limited amount of ammonia $\left(\mathrm{NH}_{3}\right)$ concentration with respect to the ammonium $\left(\mathrm{NH}_{4}^{+}\right)$one. This is mainly due to the range of $\mathrm{pH}$ of the produced leachates, which, in any case produced different amounts of $\mathrm{NH}_{3}-\mathrm{NH}_{4}^{+}$when using $\mathrm{mQ}$ or lake water (Fig. 6). In particular, the ammonia-ammonium concentration in $\mathrm{mQ}$ water is negligible for Etna samples, while it increases for 


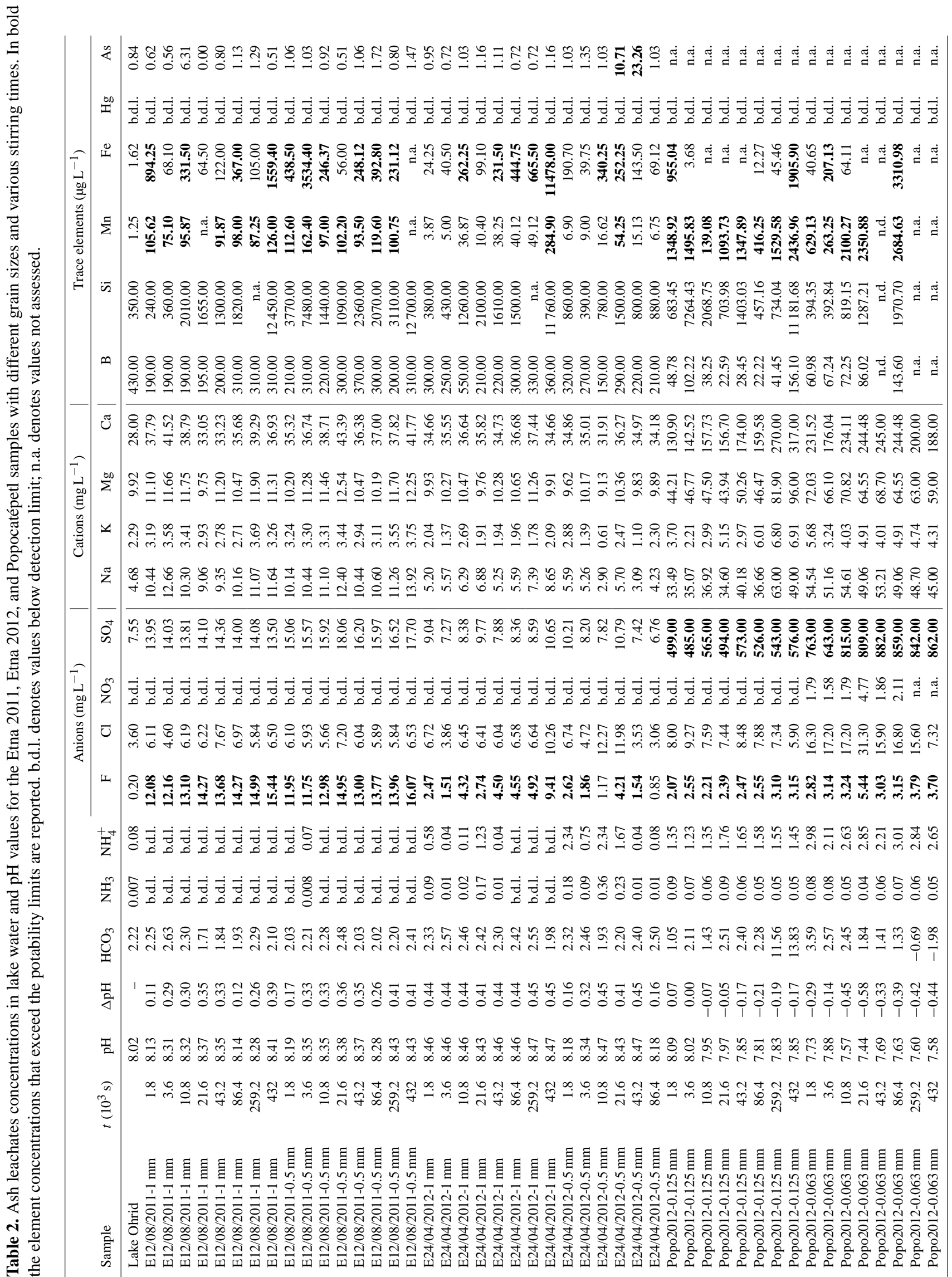


(a)

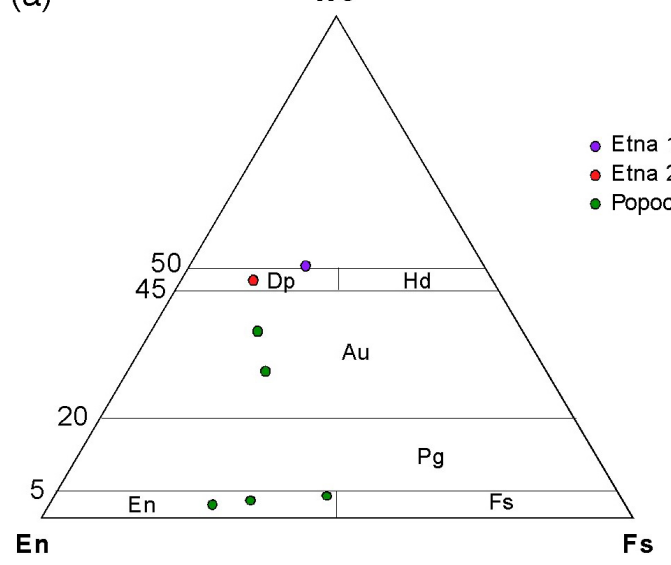

(b)

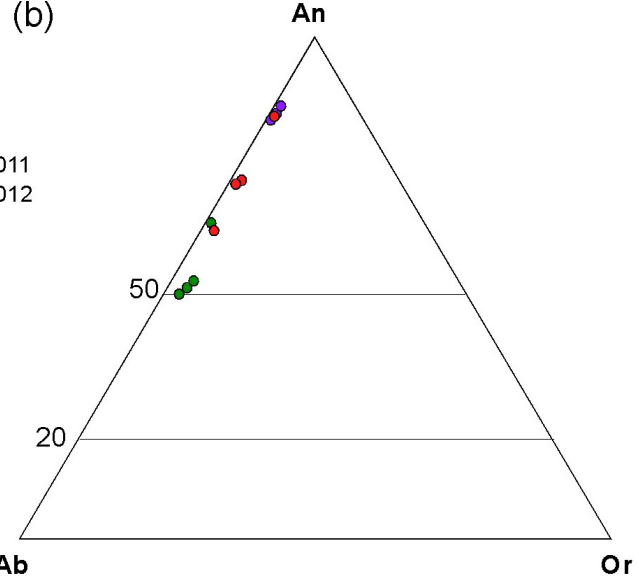

Figure 3. Ternary diagrams for the classification of (a) pyroxenes and (b) feldspars.

Popocatépetl samples. In lake water, the Popocatépetl samples release $\mathrm{NH}_{3}-\mathrm{NH}_{4}^{+}$almost constantly (variation within $1 \mathrm{mg} \mathrm{L}^{-1}$ ), while the Etna samples either do not release $\mathrm{NH}_{3}-\mathrm{NH}_{4}^{+}$(samples Etna 2011) or have a scattered release of $\mathrm{NH}_{3}-\mathrm{NH}_{4}^{+}$with time (samples Etna 2012; Fig. 6). When effective, the release of $\mathrm{NH}_{3}-\mathrm{NH}_{4}^{+}$also shows correlation with decreasing grain size (Fig. 6).

\subsubsection{Anions}

Figure 7 shows the variations of $\mathrm{F}^{-}, \mathrm{Cl}^{-}$, and $\mathrm{SO}_{4}^{2-}$ concentrations for different grain sizes vs. time of leaching. The general patterns show small variation in concentration vs. time for all anions, indicating their release occurring in the first $30 \mathrm{~min}$, with the exception of the $\mathrm{SO}_{4}^{2-}$ in $\mathrm{mQ}$ water, which reaches a constant release after $60 \mathrm{~min}$.

The concentration of $\mathrm{Cl}^{-}$is below $10 \mathrm{mg} \mathrm{L}^{-1}$ for most of the samples in both $\mathrm{mQ}$ and lake water, with the exception of Popocatépetl ash with a grain size of $63 \mu \mathrm{m}$ and some scattered anomalous values (Fig. 7).

Irrespective of water used, the release of $\mathrm{SO}_{4}^{2-}$ is negligible in Etna samples, while it is the most significant in Popocatépetl samples. For the latter, the concentration of $\mathrm{SO}_{4}^{2-}$ significantly increases with diminishing grain size and moderately increases with leaching time (Fig. 7).

The concentration pattern of $\mathrm{F}^{-}$is more complex than those of the other anions, with different release in the two types of leaching water. In particular, the 2011 Etna samples produce the greatest concentrations in both water types, although higher in $\mathrm{mQ}$ water (Fig. 7). The 2012 Etna samples show lower concentrations, and in lake water they are below $10 \mathrm{mg} \mathrm{L}^{-1}$. The Popocatépetl samples have a concentration of a few milligrams per litre (below $10 \mathrm{mg} \mathrm{L}^{-1}$ ), and a slight correlation with decreasing grain size in $\mathrm{mQ}$ water (Fig. 7). In both types of waters, all the samples show a general slight correlation with increasing leaching time.

\subsubsection{Major cations}

Figure 8 shows the variations of $\mathrm{Na}^{+}, \mathrm{K}^{+}, \mathrm{Mg}^{2+}$, and $\mathrm{Ca}^{2+}$ concentration for different grain sizes vs. time of leaching. The general patterns show small variation in concentration vs. time for all cations, indicating their release occurring generally in the first 30-60 minutes, while the Popocatépetl samples reach the highest concentration after 3-5 days in lake waters. The concentration of $\mathrm{Na}^{+}$is below $20 \mathrm{mg} \mathrm{L}^{-1}$ in Etna samples in both $\mathrm{mQ}$ and lake water, and it is between 30 and $60 \mathrm{mg} \mathrm{L}^{-1}$ in Popocatépetl samples. The concentration of $\mathrm{K}^{+}$is below $7 \mathrm{mg} \mathrm{L}^{-1}$ for most of the samples in both $\mathrm{mQ}$ and lake water, with the exception of the Etna $20121 \mathrm{~mm}$ sample in $\mathrm{mQ}$ water (Fig. 8). It is worth noting that the concentration of $\mathrm{Na}^{+}$and $\mathrm{K}^{+}$for the Etna 2012 samples in lake water leachate is close or below the concentration that these cations have in pure lake water (Fig. 8).

Irrespective of the water type used, the release of $\mathrm{Ca}^{2+}$ and $\mathrm{Mg}^{2+}$ is negligible for Etna samples, while it is the most relevant in Popocatépetl samples (Fig. 8). Their concentration increases at diminishing grain size except for lake water after $24 \mathrm{~h}$ (Fig. 8).

\subsubsection{Trace elements}

Figure 9 shows the variations of $\mathrm{B}, \mathrm{Si}, \mathrm{Fe}_{\mathrm{Tot}}, \mathrm{Mn}^{2+}$, and $\mathrm{As}^{3+}$ concentration for different grain sizes vs. time of leaching. The general patterns show irregular variation in concentration vs. time for all the trace elements. B concentration shows a scattered distribution vs. time of leaching in $\mathrm{mQ}$ water, although a fair anti-correlation is visible for three out of four Etna samples (Fig. 9). It is below the lake water concentration for almost all the analysed samples (Fig. 9). The concentration of $\mathrm{Si}$ is scattered in both $\mathrm{mQ}$ and lake water leachates, although a fair increase in concentration is visible with time of leaching for both Etna and Popocatépetl samples (Fig. 9). 

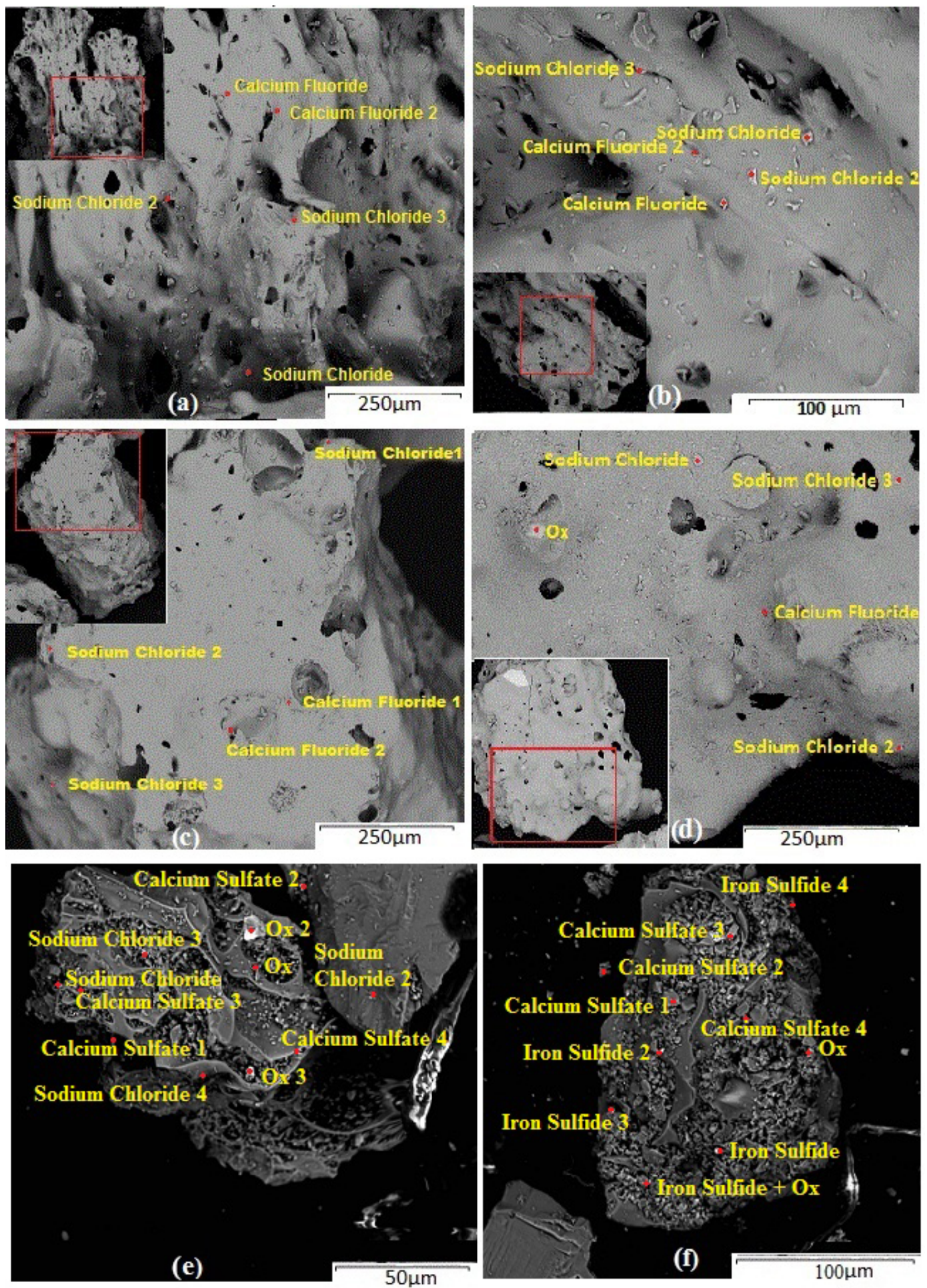

Figure 4. SEM-BSE images of fresh ash particles from Etna 2011 (a, b), Etna 2012 (c, d), and Popocatépetl samples (e, f). The insets indicate the investigated area. The detected sublimated salts are in yellow. 


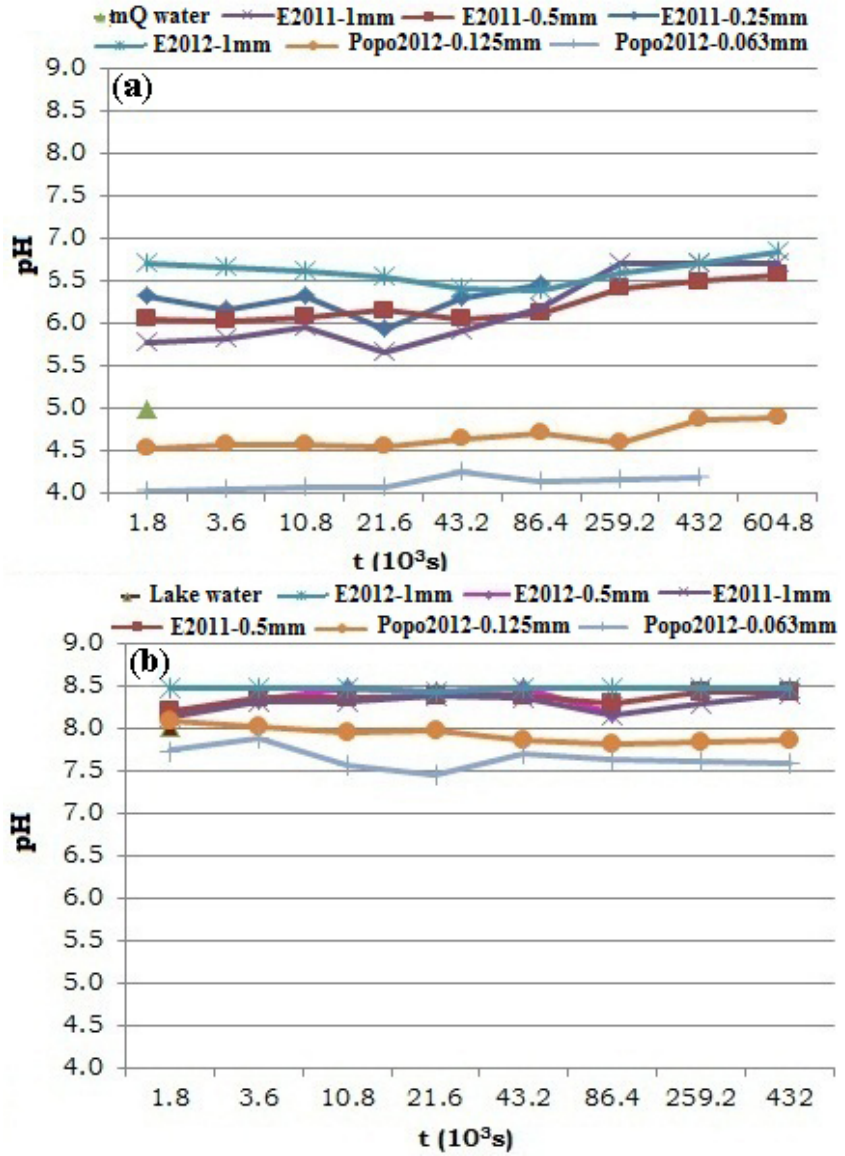

Figure 5. Panel (a) shows $\mathrm{pH}$ variation of ash leachates in mQ; and (b) $\mathrm{pH}$ variation of ash leachates in lake water. The samples were washed using variable stirring times and different grain size. The $\mathrm{pH}$ of $\mathrm{mQ}$ and lake water is indicated for comparison.

Irrespective of water typology used, the release of $\mathrm{Fe}_{\mathrm{Tot}}$ and $\mathrm{Mn}^{2+}$ is lower in Etna samples than in Popocatépetl ones, showing a scattered distribution with some very high peaks (Fig. 9).

\subsection{Biological impact of leachates}

The results from the FETAX test clearly show that the leachates from Etna and Popocatépetl ash are very poorly embryo-toxic. With the dilutions used, no significant increase in embryo mortality was indeed observed (Fig. 10a, b). The percentages of malformed larvae at the end of the test progressively increased with decreasing dilutions in the groups exposed to Etna leachates (Fig. 10a), while a non-linear increase was observed in those exposed to Popocatépetl leachates (Fig. 10b). The maximum values of about $40 \%$ malformed larvae were recorded at the highest concentrations of leachates.

These results do not evidence significant differences in the effects induced by Etna and Popocatépetl leachates, although it is worth noting the higher scores obtained in larvae exposed

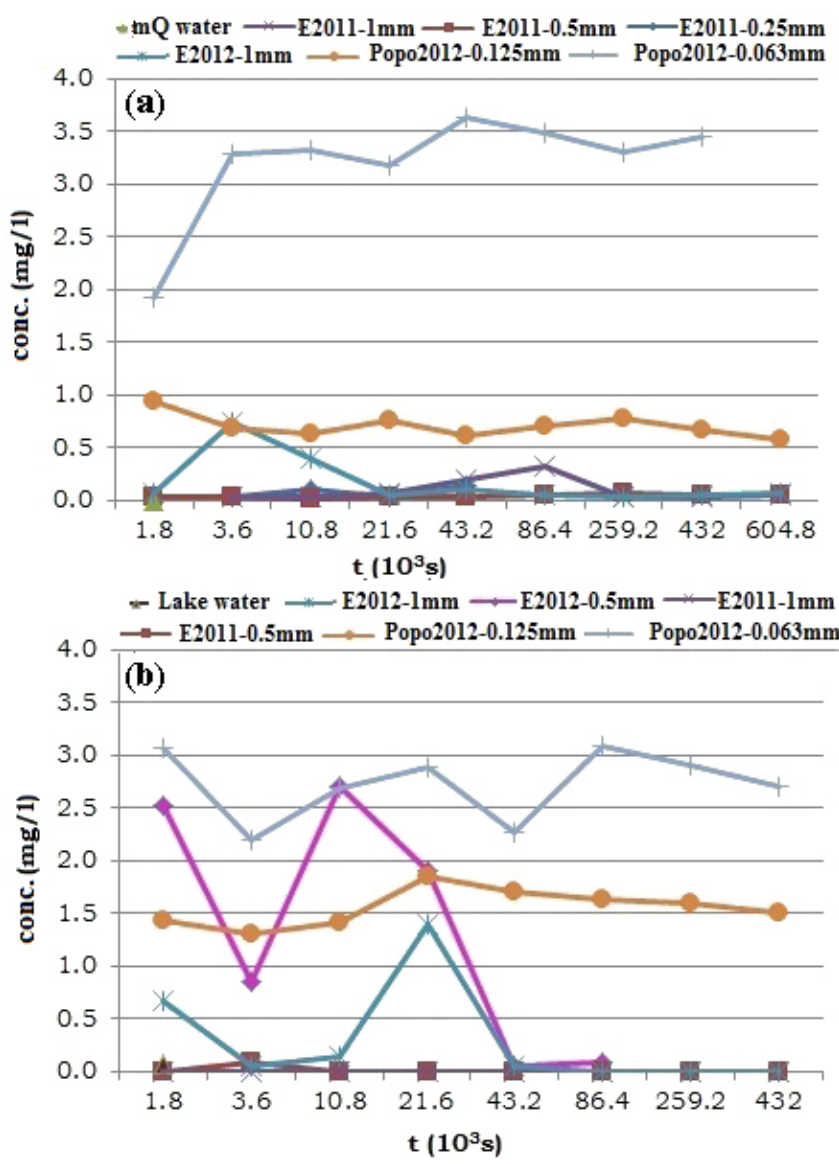

Figure 6. $\mathrm{NH}_{3}-\mathrm{NH}_{4}^{+}$variation of ash leachates in (a) $\mathrm{mQ}$; and (b) lake water for variable stirring times and different grain sizes. The $\mathrm{NH}_{3}$ content of $\mathrm{mQ}$ and lake water is indicated for comparison.

to Etna leachates at low concentrations $(1: 100$ and $1: 50)$, with respect to the Popocatépetl ones.

\section{Discussion}

\subsection{General remarks}

The data presented in the preceding sections illustrate the complexity that accompanies the leaching of compounds from fresh volcanic ash. Analysing the figures and the tables presented, it emerges clearly how the physical and chemical processes occurring during the simple washing of fresh volcanic ash interact with the surrounding aqueous environment. It follows that to extract simple laws of compound release at different boundary conditions is not straightforward. This is because we have to face dynamic processes that change in function of the progressive variation of the experimental geochemical environment.

In the following, we analyse the data, taking into account the major variables potentially influencing the experimental 

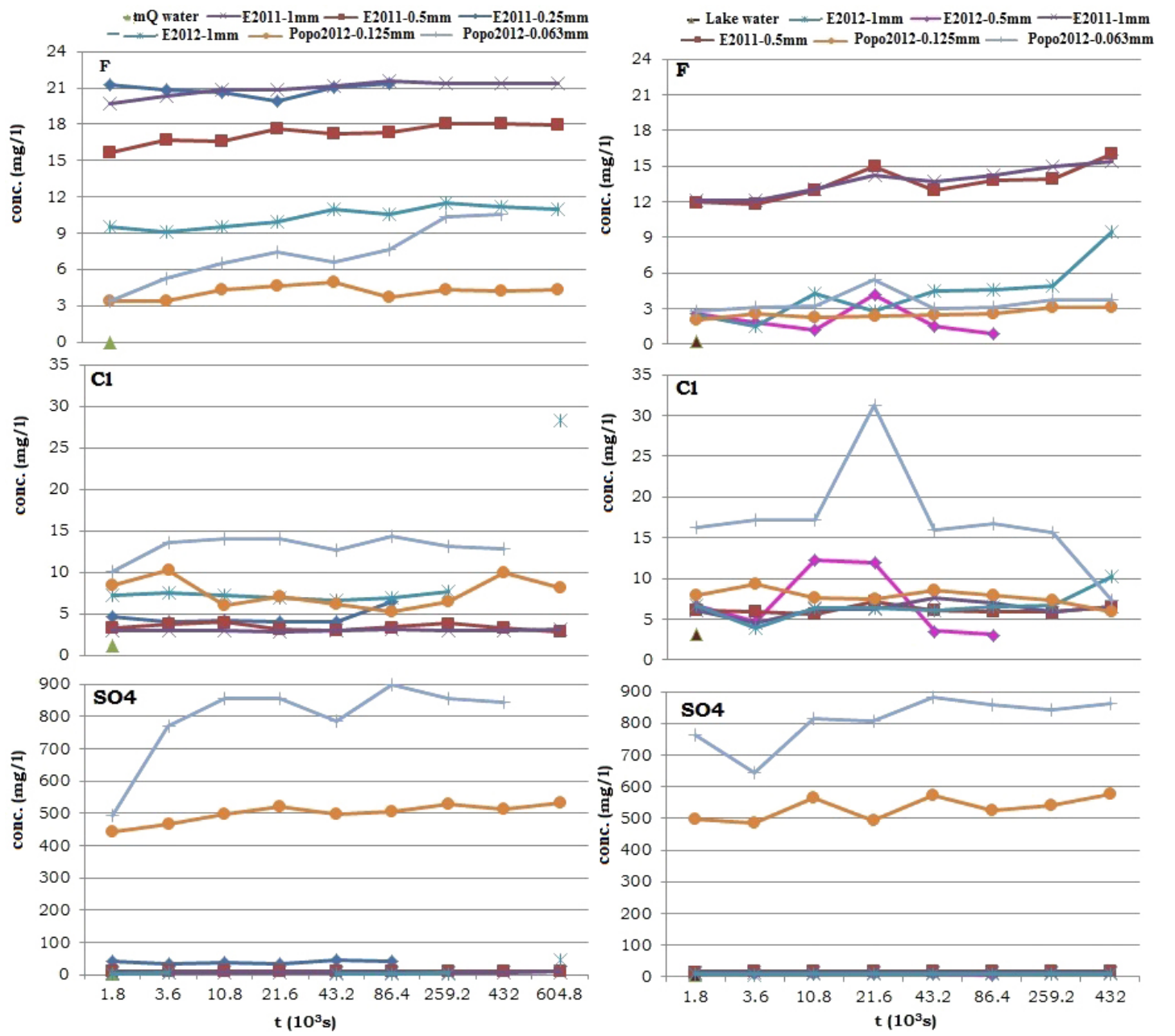

Figure 7. Anions' $\left(\mathrm{Cl}^{-}, \mathrm{SO}_{4}^{2-}\right.$, and $\mathrm{F}^{-}$) variation of ash leachates in $\mathrm{mQ}$ (left column) and in lake water (right column) for variable stirring times and different grain sizes. The different anions' contents of $\mathrm{mQ}$ and lake water are reported for comparison.

results. Finally, the potential toxicity of ash leachates will be discussed in the light of potable water pollution and alteration of life cycle of living biota (tadpoles embryos, Xenopus laevis).

\subsection{Origin of leached elements}

The mQ water is almost pure water; thus it does not contains any other element or compound that could react with the leaching material. Therefore, it is more suitable for the analysis of leached compounds from volcanic ash than lake water, whose dissolved elements and molecules can react with leached elements and alter their original assemblage.

The sublimates on ash surfaces of Etna 2011 (Fig. 4a and b) include mainly $(\mathrm{Na}, \mathrm{K}) \mathrm{Cl}$ (sodium/potassium chloride), $(\mathrm{Ca}, \mathrm{Mg}) \mathrm{F}_{2}$ (calcium/magnesium fluoride), and $(\mathrm{Ca}, \mathrm{Mg}) \mathrm{SO}_{4}$ (calcium/magnesium sulfate). The formation of leachates from solubilization of these superficial salts is also confirmed by the stoichiometry of $\mathrm{mQ}$ water analysis, in which the rel- ative abundance of these elements is almost completely balanced. Only few residual fractions of $\mathrm{Ca}^{2+}, \mathrm{Mg}^{2+}$, and $\mathrm{F}^{-}$ scattered in the different grain size fractions remain unbalanced (Table S4). The concentration of all the elements is below their respective solubility limit, except for $\mathrm{Si}^{2+}$ and $\mathrm{F}^{-}$(Table S5). It means that all the salts from the ash surface passed into the leachates, with the exception of Si and F salts, which may have remained partially not dissolved. The slight excess of $\mathrm{Mg}^{2+}$ and $\mathrm{Ca}^{2+}$ in most of the Etna 2011 samples (Table S4) might indicate the presence of carbonates in the leachates, since $\mathrm{CO}_{3}^{2-}$ was not analysed. When considering the stoichiometry of the leachates, it emerges that $\mathrm{F}^{-}$compounds are the most dissolved in Etna 2011 samples, along with variable amount of $\mathrm{SO}_{4}^{2-}$ and minor $\mathrm{Cl}^{-}$compounds (Table S4).

The Etna 2012 sample shows very similar stoichiometry of leachates to Etna 2011, with fractional remnants of unbalanced elements that comprise $\mathrm{K}^{+}, \mathrm{Ca}^{2+}$, and $\mathrm{Mg}^{2+}$ (Table $\mathrm{S} 4) . \mathrm{Mg}$ concentration is close to the maximum solubil- 

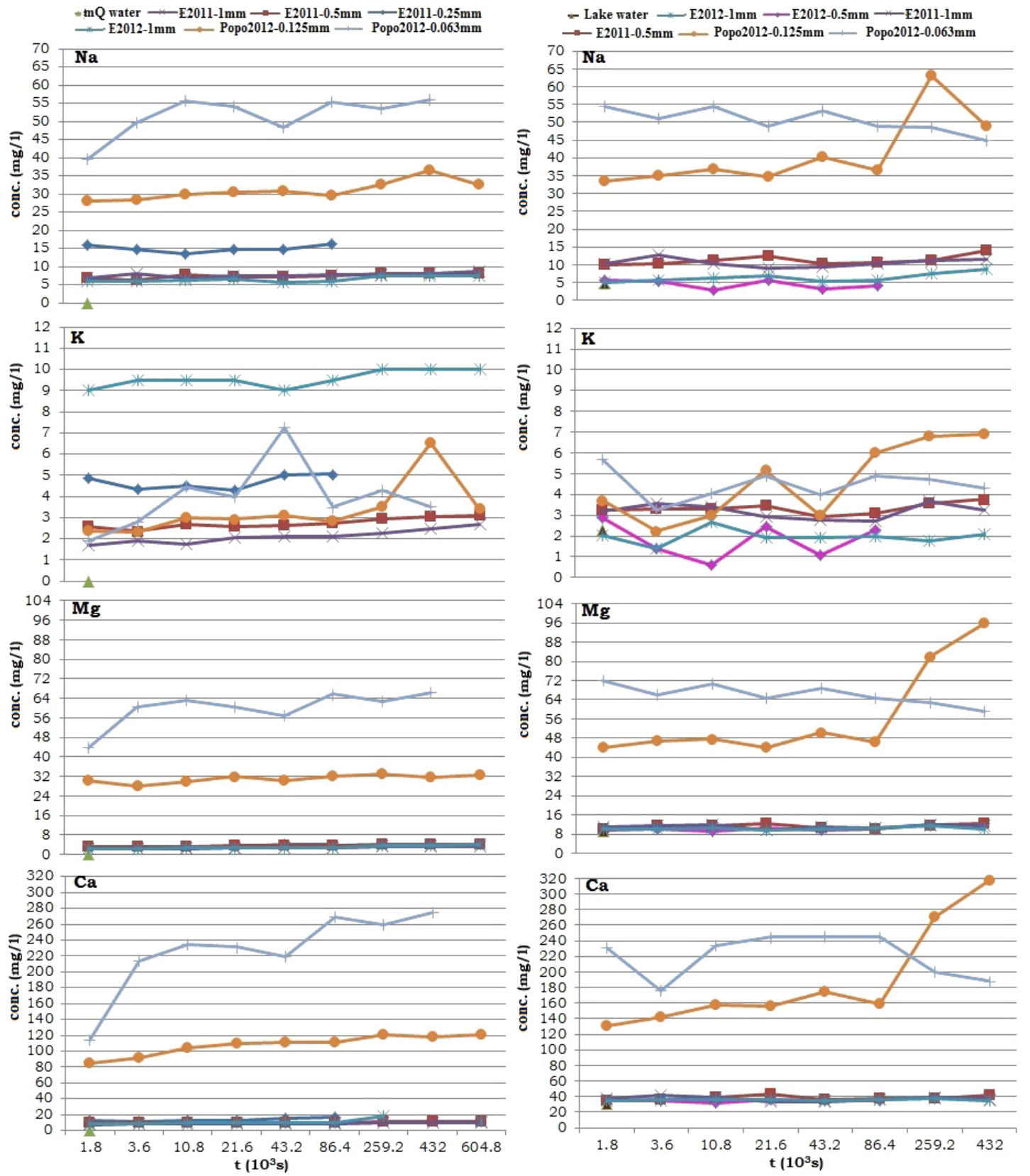

Figure 8. Cations' $\left(\mathrm{Na}^{+}, \mathrm{K}^{+}, \mathrm{Ca}^{2+}\right.$, and $\mathrm{Mg}^{2+}$ ) variation of ash leachates in $\mathrm{mQ}$ (left column) and in lake water (right column) for variable stirring times and different grain sizes. The different cations' contents of $\mathrm{mQ}$ and lake water are reported for comparison.

ity limit, and dissolved $\mathrm{F}$ compounds dominate the leachates (Table S4).

The sublimates on ash surfaces of Popocatépetl samples (Fig. 4e and f) include mainly $(\mathrm{Ca}, \mathrm{Mg}) \mathrm{SO}_{4}$ (calcium/magnesium sulfate) and minor $(\mathrm{Na}, \mathrm{K}) \mathrm{Cl}$ (sodium/potassium chloride). Also in these cases the leachates reflect the dissolution of the salts observed on ash surfaces, as confirmed by stoichiometric calculations (Table S4). A slight excess of $\mathrm{Mg}^{2+}, \mathrm{Ca}^{2+}, \mathrm{K}^{+}$, and $\mathrm{Na}^{+}$not balanced by $\mathrm{Cl}^{-}, \mathrm{SO}_{4}^{2-}$, and $\mathrm{F}^{-}$is observed, which might indicate the occurrence of carbonates (not analysed) in the leachates. The concentration of elements in the two samples $(0.125$ and $0.063 \mathrm{~mm})$ slightly differs (Table S5), with the coarser one that shows saturation with respect to $\mathrm{Ca}, \mathrm{Si}$, and Fe compounds, and the finer one that shows saturation in fluorite, gypsum, quartz, and chalcedony (Table S5). The $\mathrm{Mg}^{2+}$ content in $\mathrm{mQ}$ leachates from Popocatépetl samples is higher than in Etna samples (Table S4). Taking into account the surface analysis on sublimates, it seems that most of the $\mathrm{Mg}^{2+}$ comes from the dissolution of Mg-sulfates. 

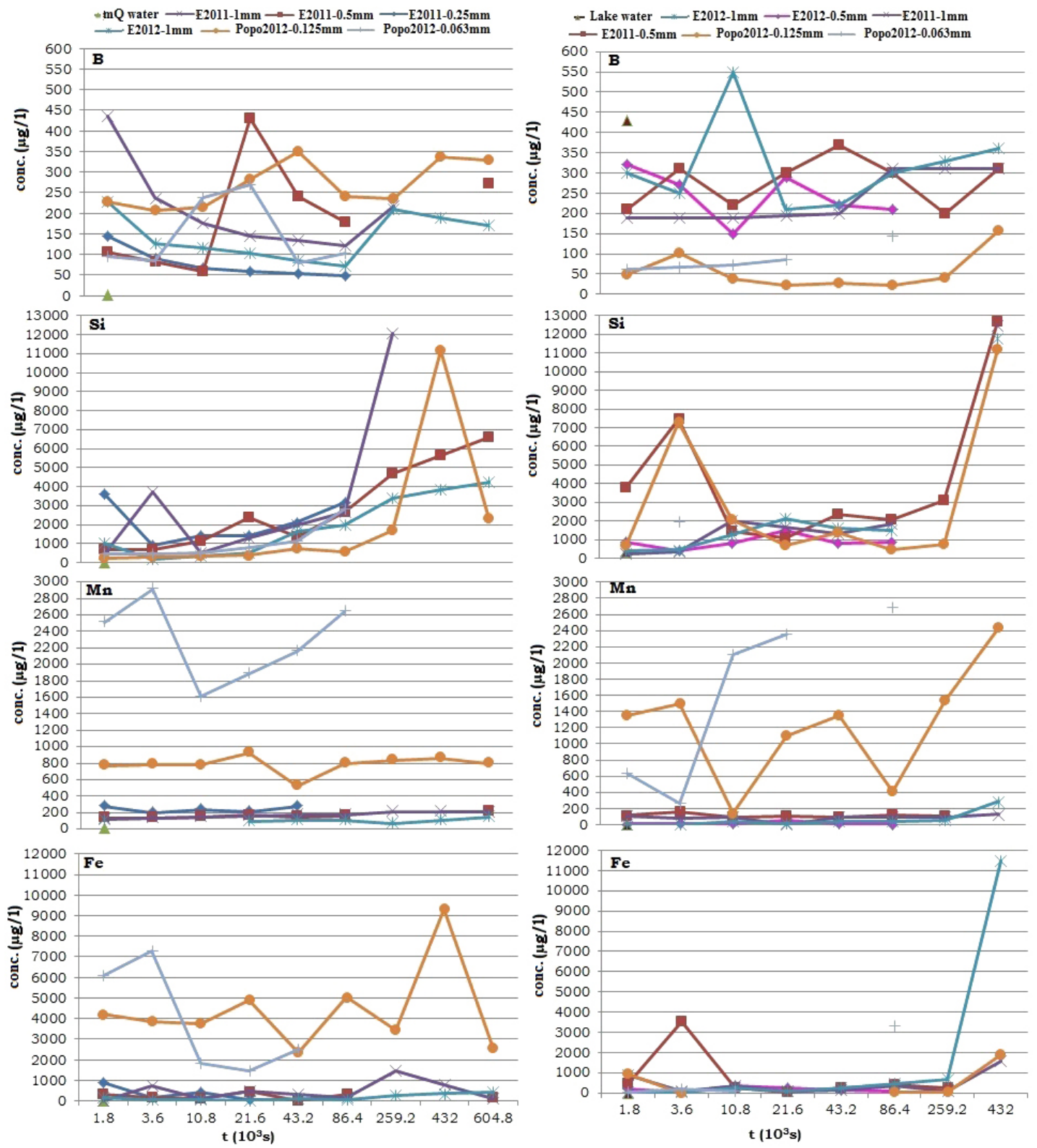

Figure 9. Trace elements' $\left(\mathrm{B}^{-}, \mathrm{Si}^{2+}, \mathrm{Mn}^{2+}\right.$, and $\mathrm{Fe}$ ) variation of ash leachates in $\mathrm{mQ}$ (left column) and in lake water (right column) for variable stirring times and different grain sizes. The different trace elements' contents of $\mathrm{mQ}$ and lake water are reported for comparison.

This inference is also supported by the strong correlation among $\mathrm{Ca}^{2+}, \mathrm{Mg}^{2+}$, and $\mathrm{NH}_{4}^{+}$(Fig. 11), which indicates the presence of the ammonium as catalyst for $(\mathrm{Ca}, \mathrm{Mg})$ salt dissolution.

The composition of leachates in lake water can be quite different from those in $\mathrm{mQ}$ water, due to the presence of chemical compounds already present, which can react with elements released from ash surface (Table 2). In order to evaluate the buffering effect of lake water, its chemical composition was subtracted from that of the leachates (Table 3 ). This allows the net release of the different elements to be compared using the two water typologies. It is evident com- paring data from Tables 1 and 3 how the release of elements from Etna samples is variably lower in lake water than in the $\mathrm{mQ}$ one, with loss of some $10 \%$ in abundance of $\mathrm{F}^{-}$, $\mathrm{K}^{+}, \mathrm{Mg}^{2+}, \mathrm{Mn}^{2+}$ and especially $\mathrm{B}$, which has a negative net release in lake water (Table 3). This general behaviour is also confirmed by Popocatépetl samples, with the exceptions of a greater release of $\mathrm{Mg}^{2+}$ and $\mathrm{Ca}^{2+}$ in lake water for the $125 \mu \mathrm{m}$ fraction (Table 3 ). Because borates are usually highly soluble, it may suggest the occurrence of adsorption/reaction processes of B with compounds present in lake water.

Regarding the Lake Ohrid water from carbonate springs, the described variations in element abundance between $\mathrm{mQ}$ 
Table 3. Net release of leachates in lake water for the Etna 2011, Etna 2012, and Popocatépetl samples with different grain sizes and various stirring times. Italics indicate the negative release of elements in lake water. b.d.l. denotes values below detection limit; n.a. denotes values not assessed.

\begin{tabular}{|c|c|c|c|c|c|c|c|c|c|c|c|c|c|}
\hline \multirow[b]{2}{*}{ Sample } & \multirow[b]{2}{*}{$t\left(10^{3} \mathrm{~s}\right)$} & \multicolumn{4}{|c|}{ Anions $\left(\mathrm{mg} \mathrm{L}^{-1}\right)$} & \multicolumn{3}{|c|}{ Cations ( $\mathrm{mg} \mathrm{L}^{-1}$ ) } & \multicolumn{5}{|c|}{ Trace elements ( $\mu \mathrm{g} \mathrm{L})$} \\
\hline & & $\mathrm{F}$ & $\mathrm{Cl}$ & $\mathrm{SO}_{4}$ & $\mathrm{Na}$ & $\mathrm{K}$ & $\mathrm{Mg}$ & $\mathrm{Ca}$ & B & $\mathrm{Si}$ & $\mathrm{Mn}$ & $\mathrm{Fe}$ & As \\
\hline E12/08/2011-1 mm & 1.8 & 11.88 & 2.51 & 6.40 & 5.76 & 0.90 & 1.18 & 9.79 & -240.00 & -110.00 & 104.37 & 892.63 & -0.22 \\
\hline E12/08/2011-1 mm & 3.6 & 11.96 & 1.00 & 6.48 & 7.98 & 1.29 & 1.74 & 13.52 & -240.00 & 10.00 & 73.85 & 66.48 & -0.28 \\
\hline E12/08/2011-1 mm & 10.8 & 12.90 & 2.59 & 6.26 & 5.62 & 1.12 & 1.83 & 10.79 & -240.00 & 1660.00 & 94.62 & 329.88 & 5.47 \\
\hline E12/08/2011-1 mm & 21.6 & 14.07 & 2.62 & 6.55 & 4.38 & 0.64 & -0.17 & 5.05 & -235.00 & 1305.00 & -1.25 & 62.88 & -0.84 \\
\hline E12/08/2011-1 mm & 43.2 & 13.48 & 4.07 & 6.81 & 4.67 & 0.49 & 1.28 & 5.23 & -230.00 & 950.00 & 90.62 & 120.38 & -0.04 \\
\hline $\mathrm{E} 12 / 08 / 2011-1 \mathrm{~mm}$ & 86.4 & 14.07 & 3.37 & 6.45 & 5.48 & 0.42 & 0.55 & 7.68 & -120.00 & 1470.00 & 96.75 & 365.38 & 0.29 \\
\hline E12/08/2011-1 mm & 259.2 & 14.79 & 2.24 & 6.53 & 6.39 & 1.40 & 1.98 & 11.29 & -120.00 & n.a. & 86.00 & 103.38 & 0.45 \\
\hline E12/08/2011-1 mm & 432 & 15.24 & 2.90 & 5.95 & 6.96 & 0.97 & 1.39 & 8.93 & -120.00 & 12100.00 & 124.75 & 1557.78 & -0.33 \\
\hline E12/08/2011-0.5 mm & 1.8 & 11.75 & 2.50 & 7.51 & 5.46 & 0.95 & 0.28 & 7.32 & -220.00 & 3420.00 & 111.35 & 436.88 & 0.22 \\
\hline $\mathrm{E} 12 / 08 / 2011-0.5 \mathrm{~mm}$ & 3.6 & 11.55 & 2.33 & 8.02 & 5.76 & 1.01 & 1.36 & 8.74 & -120.00 & 7130.00 & 161.15 & 3532.78 & 0.19 \\
\hline $\mathrm{E} 12 / 08 / 2011-0.5 \mathrm{~mm}$ & 10.8 & 12.78 & 2.06 & 8.37 & 6.42 & 1.02 & 1.54 & 10.71 & -210.00 & 1090.00 & 95.75 & 244.75 & 0.08 \\
\hline $\mathrm{E} 12 / 08 / 2011-0.5 \mathrm{~mm}$ & 21.6 & 14.75 & 3.60 & 10.51 & 7.72 & 1.15 & 2.62 & 15.39 & -130.00 & 740.00 & 100.95 & 54.38 & -0.33 \\
\hline $\mathrm{E} 12 / 08 / 2011-0.5 \mathrm{~mm}$ & 43.2 & 12.80 & 2.44 & 8.65 & 5.76 & 0.65 & 0.55 & 8.38 & -60.00 & 2010.00 & 92.25 & 246.50 & 0.22 \\
\hline $\mathrm{E} 12 / 08 / 2011-0.5 \mathrm{~mm}$ & 86.4 & 13.57 & 2.29 & 8.42 & 5.92 & 0.82 & 0.27 & 9.00 & -130.00 & 1720.00 & 118.35 & 391.18 & 0.88 \\
\hline $\mathrm{E} 12 / 08 / 2011-0.5 \mathrm{~mm}$ & 259.2 & 13.76 & 2.24 & 8.97 & 6.58 & 1.26 & 1.78 & 9.82 & -230.00 & 2760.00 & 99.50 & 229.50 & -0.04 \\
\hline E12/08/2011-0.5 mm & 432 & 15.87 & 2.93 & 10.15 & 9.24 & 1.46 & 2.33 & 13.77 & -120.00 & 12350.00 & n.a. & n.a. & 0.63 \\
\hline E24/04/2012-1 mm & 1.8 & 2.27 & 3.12 & 1.49 & 0.52 & -0.25 & 0.01 & 6.66 & -130.00 & 30.00 & 2.62 & 22.63 & 0.11 \\
\hline E24/04/2012-1 mm & 3.6 & 1.31 & 0.26 & -0.28 & 0.89 & -0.92 & 0.35 & 7.55 & -180.00 & 80.00 & 3.75 & 38.88 & -0.12 \\
\hline E24/04/2012-1 mm & 10.8 & 4.12 & 2.85 & 0.83 & 1.61 & 0.40 & 0.55 & 8.64 & 120.00 & 910.00 & 35.62 & 260.63 & 0.19 \\
\hline E24/04/2012-1 mm & 21.6 & 2.54 & 2.81 & 2.22 & 2.20 & -0.38 & -0.16 & 7.82 & -220.00 & 1750.00 & 9.15 & 97.48 & 0.32 \\
\hline E24/04/2012-1 mm & 43.2 & 4.30 & 2.44 & 0.33 & 0.57 & -0.35 & 0.36 & 6.73 & -210.00 & 1260.00 & 37.00 & 229.88 & 0.27 \\
\hline E24/04/2012-1 mm & 86.4 & 4.35 & 2.98 & 0.81 & 0.91 & -0.33 & 0.73 & 8.68 & -130.00 & 1150.00 & 38.87 & 443.13 & -0.12 \\
\hline $\mathrm{E} 24 / 04 / 2012-1 \mathrm{~mm}$ & 259.2 & 4.72 & 3.04 & 1.04 & 2.71 & -0.51 & 1.34 & 9.44 & -100.00 & n.a. & 47.87 & 663.88 & -0.12 \\
\hline E24/04/2012-1 mm & 432 & 9.21 & 6.66 & 3.10 & 3.97 & -0.20 & -0.01 & 6.66 & -70.00 & 11410.00 & 283.65 & 11476.38 & 0.32 \\
\hline E24/04/2012-0.5 mm & 1.8 & 2.42 & 3.14 & 2.66 & 0.91 & 0.59 & -0.30 & 6.86 & -110.00 & 510.00 & 5.65 & 189.08 & 0.19 \\
\hline E24/04/2012-0.5 mm & 3.6 & 1.66 & 1.12 & 0.65 & 0.58 & -0.90 & 0.25 & 7.01 & -160.00 & 40.00 & 7.75 & 38.13 & 0.51 \\
\hline E24/04/2012-0.5 mm & 10.8 & 0.97 & 8.67 & 0.27 & -1.78 & -1.68 & -0.79 & 3.91 & -280.00 & 430.00 & 15.37 & 338.63 & 0.19 \\
\hline E24/04/2012-0.5 mm & 21.6 & 4.01 & 8.38 & 3.24 & 1.02 & 0.18 & 0.44 & 8.27 & -140.00 & 1150.00 & 53.00 & 250.63 & 9.87 \\
\hline E24/04/2012-0.5 mm & 43.2 & 1.34 & -0.07 & -0.13 & -1.59 & -1.19 & -0.09 & 6.97 & -210.00 & 450.00 & 13.88 & 141.88 & 22.42 \\
\hline E24/04/2012-0.5 mm & 86.4 & 0.65 & -0.54 & -0.79 & -0.45 & 0.01 & -0.03 & 6.18 & -220.00 & 530.00 & 5.50 & 67.50 & 0.19 \\
\hline Рopo2012-0.125 mm & 1.8 & 1.87 & 4.40 & 491.45 & 28.81 & 1.41 & 34.29 & 102.90 & -381.22 & 333.45 & 1347.67 & 953.42 & n.a. \\
\hline Роро2012-0.125 mm & 3.6 & 2.35 & 5.67 & 477.45 & 30.39 & -0.08 & 36.85 & 114.52 & -327.78 & 6914.43 & 1494.58 & 2.06 & n.a. \\
\hline Popo2012-0.125 mm & 10.8 & 2.01 & 3.99 & 557.45 & 32.24 & 0.70 & 37.58 & 129.73 & -391.75 & 1718.75 & 137.83 & n.a. & n.a. \\
\hline Роро2012-0.125 mm & 21.6 & 2.19 & 3.84 & 486.45 & 29.92 & 2.86 & 34.02 & 128.70 & -407.41 & 353.98 & 1092.48 & n.a. & n.a. \\
\hline Роро2012-0.125 mm & 43.2 & 2.27 & 4.88 & 565.45 & 35.50 & 0.68 & 40.34 & 146.00 & -401.55 & 1053.03 & 1346.64 & n.a. & n.a. \\
\hline Роро2012-0.125 mm & 86.4 & 2.35 & 4.28 & 518.45 & 31.98 & 3.72 & 36.55 & 131.58 & -407.78 & 107.16 & 415.00 & 10.65 & n.a. \\
\hline Рopo2012-0.125 mm & 259.2 & 2.90 & 3.74 & 535.45 & 58.32 & 4.51 & 71.98 & 242.00 & -388.55 & 384.04 & 1528.33 & 43.84 & n.a. \\
\hline Рopo2012-0.125 mm & 432 & 2.95 & 2.30 & 568.45 & 44.32 & 4.62 & 86.08 & 289.00 & -273.90 & 10831.68 & 2435.71 & 1904.28 & n.a. \\
\hline Рopo2012-0.063 mm & 1.8 & 2.62 & 12.70 & 755.45 & 49.86 & 3.39 & 62.11 & 203.52 & -369.02 & 44.35 & 627.88 & 39.03 & n.a. \\
\hline Popo2012-0.063 mm & 3.6 & 2.94 & 13.60 & 635.45 & 46.48 & 0.95 & 56.18 & 148.04 & -362.76 & 42.84 & 262.00 & 205.51 & n.a. \\
\hline Роро2012-0.063 mm & 10.8 & 3.04 & 13.60 & 807.45 & 49.93 & 1.74 & 60.90 & 206.11 & -357.75 & 469.15 & 2099.02 & 62.49 & n.a. \\
\hline Рopo2012-0.063 mm & 21.6 & 5.24 & 27.70 & 801.45 & 44.38 & 2.62 & 54.63 & 216.48 & -343.98 & 937.21 & 2349.63 & n.a. & n.a. \\
\hline Popo2012-0.063 mm & 43.2 & 2.83 & 12.30 & 874.45 & 48.53 & 1.72 & 58.78 & 217.00 & n.a. & n.a. & n.a. & n.a. & n.a. \\
\hline Popo2012-0.063 mm & 86.4 & 2.95 & 13.20 & 851.45 & 44.38 & 2.62 & 54.63 & 216.48 & -286.40 & 1620.70 & 2683.38 & 3309.36 & n.a. \\
\hline Рopo2012-0.063 mm & 259.2 & 3.59 & 12.00 & 834.45 & 44.02 & 2.45 & 53.08 & 172.00 & n.a. & n.a. & n.a. & n.a. & n.a. \\
\hline Роро2012-0.063 mm & 432 & 3.50 & 3.72 & 854.45 & 40.32 & 2.02 & 49.08 & 160.00 & n.a. & n.a. & n.a. & n.a. & n.a. \\
\hline
\end{tabular}

and lake water can be influenced by the presence of carbonates in the latter. Although carbonates have not been measured directly, their abundance can be calculated using charge balance (Qu et al., 2008; Table 2). However, examination of $\mathrm{HCO}_{3}^{-}$data in Table 2 shows that the leachates from both Etna and Popocatépetl samples have indistinguishable contents (in average) with respect to the lake water, with the only exceptions of the Popocatépetl samples with longer stirring times. This indicates that the net release of $\mathrm{Mg}^{2+}$ and $\mathrm{Ca}^{2+}$ is limited by the reached solubility limit of most of the leachates (Table S6) in the carbonate-bearing water.

\subsection{Influence of ash grain size on leachates}

It has been suggested that concentration of deposited species on surface particles depends upon the size fraction of the tephra, and it is higher for smaller particles (Fruchter et al., 1980; Rose et al., 1973; Óskarsson, 1980; Rubin et al., 1994). Particles with smaller diameters have a higher surface area to mass ratio than larger particles so are more efficient scavengers of volatiles for the same tephra volume. This means that as the particle size decreases, the proportion of available scavenged volatiles increases (Witham et al., 2005). 

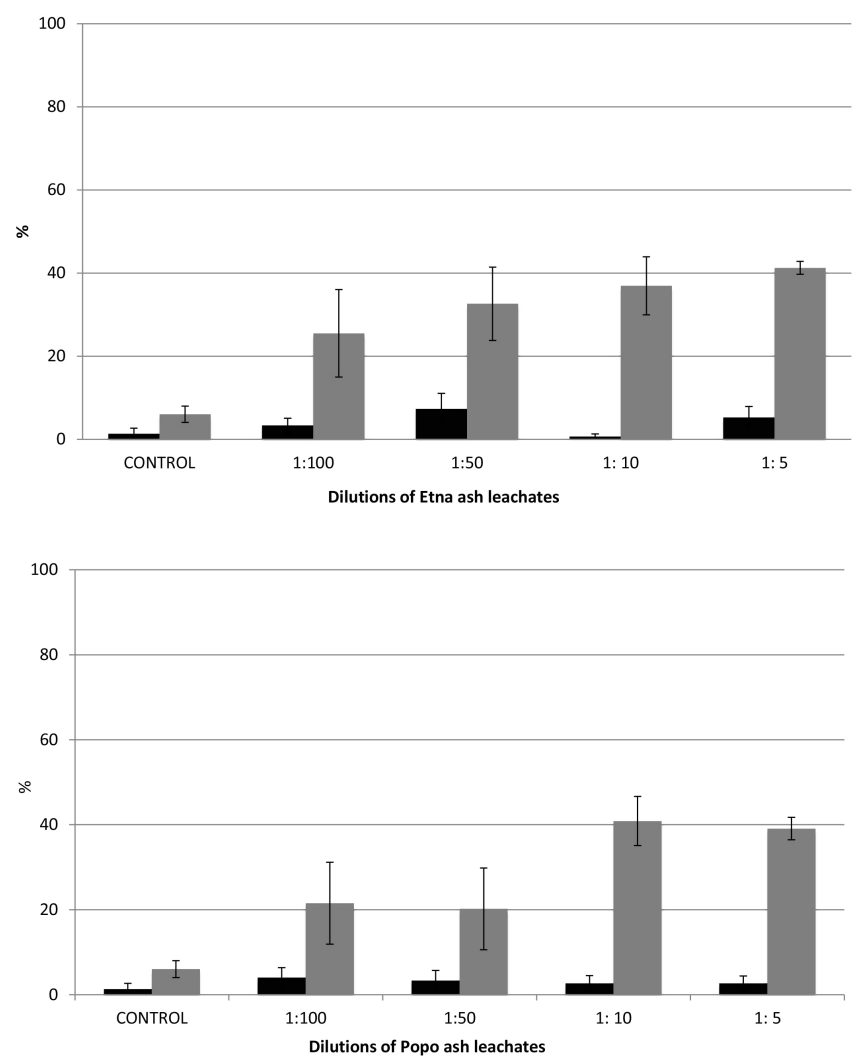

Figure 10. Results of the FETAX test with ash leachates from Etna 2012 (top panel) and Popocatépetl (bottom panel). Black histograms denote mortality \%; grey histograms denote malformed larvae \%; bars denote standard error of the mean.

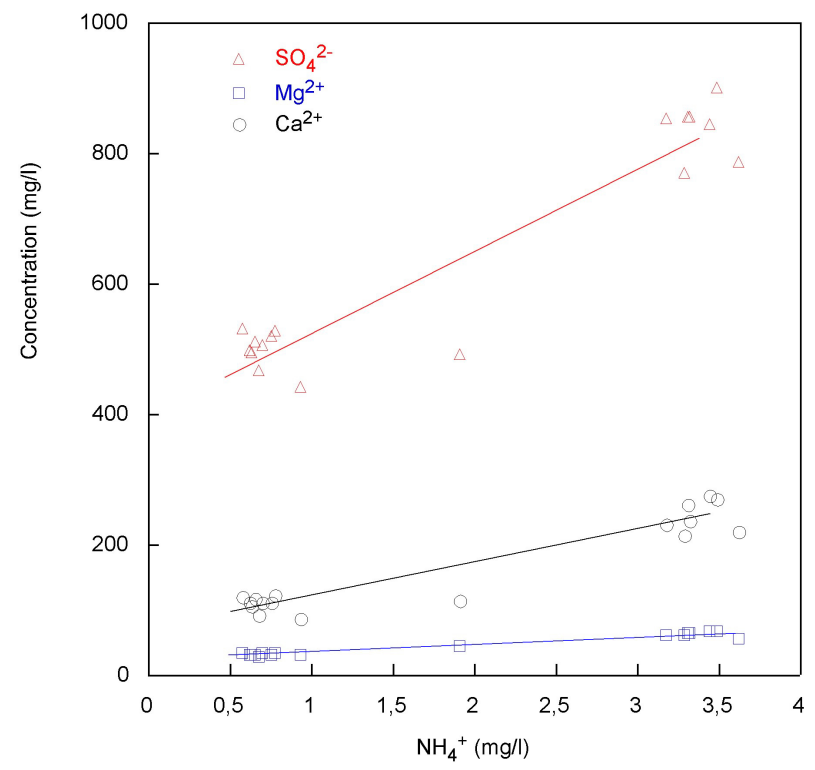

Figure 11. Correlation of $\mathrm{Ca}^{2+}, \mathrm{Mg}^{2+}$, and $\mathrm{SO}_{4}^{2-}$ vs. $\mathrm{NH}_{4}^{+}$for Popocatépetl samples.
In order to investigate the influence of grain size of ash on release of elements, the Etna 2011 samples in $\mathrm{mQ}$ water are the most suitable, as the leachates are available from three different grain sizes (Table 1). By analysing the release of elements with different stirring times, the inverse correlation with grain size is evident for $\mathrm{SO}_{4}^{2-}, \mathrm{Na}^{+}, \mathrm{K}^{+}$, and $\mathrm{Ca}^{2+}$. The trends for these elements are quite similar for the different stirring times, indicating a time-independent release for these elements (Fig. 12). A general decrease of release with increasing grain size is visible for $\mathrm{Cl}^{-}$, although the trends for different stirring times are not identical (Fig. 12). Release of $\mathrm{Mg}^{2+}$ is almost constant for the different grain sizes and for different stirring times. The release of $\mathrm{Mn}^{2+}$ is contrasting. It is inversely related to grain size for stirring times up to $21600 \mathrm{~s}(6 \mathrm{~h})$, while it increases with grain size for stirring times of $43200 \mathrm{~s}(12 \mathrm{~h})$ and $86400 \mathrm{~s}$ (24 h; Fig. 11). B also shows a similar pattern, with opposite trends below and above $21600 \mathrm{~s} \mathrm{(6h;} \mathrm{Fig.} \mathrm{11).} \mathrm{These} \mathrm{behaviours} \mathrm{suggest} \mathrm{dif-}$ ferent kinetics for the dissolution of sublimates containing $\mathrm{Mn}^{2+}$ and $\mathrm{B}$ and the precipitation of their salts.

The release of $\mathrm{F}^{-}$shows a unique pattern, with similar values for 0.25 and $1 \mathrm{~mm}$ grain sizes and lower values for the $0.5 \mathrm{~mm}$ grain size (Fig. 12). This behaviour is quite well defined by all the stirring times, which indicates this is not an aleatory behaviour. Finally, the patterns of $\mathrm{Si}$ and $\mathrm{Fe}$ are randomly arranged, without any clear correlation of release with grain size and/or timing of stirring (Fig. 12). The different patterns for the various elements of Etna 2011 samples demonstrate how the dependence of element release with grain size is not a general rule. Indeed, a greater release at decreasing grain size holds for alkali and alkaline earth elements together with the sulfate radical $\mathrm{SO}_{4}^{2-}$, which is a component of most of their original sublimated salts. This is in agreement with a greater capacity of particles with larger surface vs. volume ratio to scavenge elements from the eruptive cloud already suggested.

The release of B seems to reflect a complex kinetic of adsorption/reaction of $\mathrm{B}$, which can account for the difference in release at different stirring times (Fig. 12).

The scatter release of $\mathrm{Fe}$ and $\mathrm{Si}$ reflects the random formation of soluble salts of these elements, which are not related to the grain size but more probably to the redox conditions at the time of sublimation.

Among the most abundant elements, $\mathrm{F}^{-}$shows a unique pattern, and its explanation is puzzling. It is not related to the active surface of the particles, nor to the composition of the eruptive plume, all the particles having undergone the same eruptive conditions. It may be speculated that some gaseous $\mathrm{F}$ might be entrapped in the vesicles that are more abundant in the $1 \mathrm{~mm}$ particles than in the 0.25 and $0.5 \mathrm{~mm}$ particles, and then may be related to the presence of gaseous $\mathrm{F}$ in the vesicles of the coarse ash particles of $1 \mathrm{~mm}$ grain size, which can compensate the lower active surface of this grain size.

Exploring the dependence of element release with grain size for Popocatépetl samples is less significant, since only 

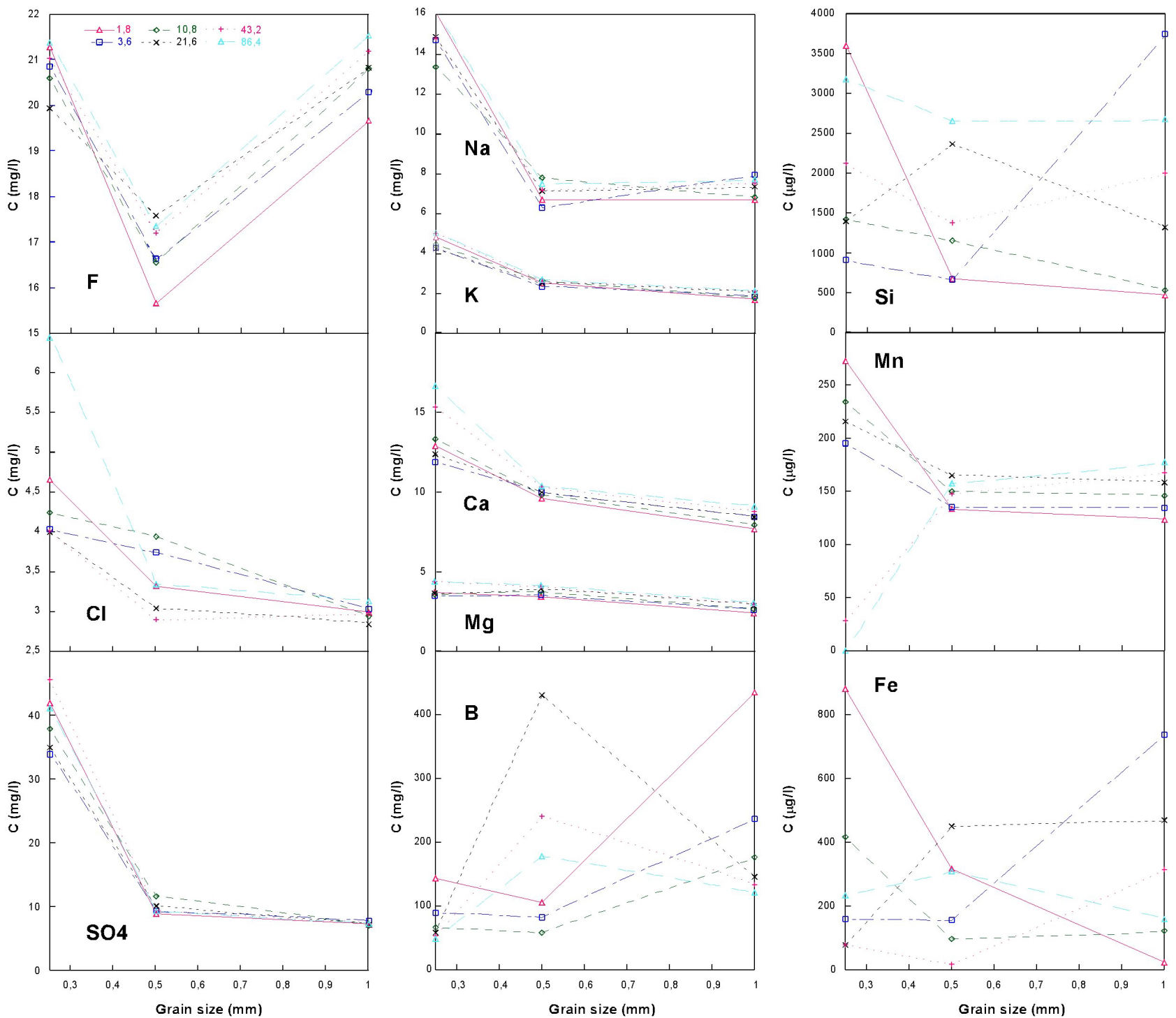

Figure 12. Dependence of element release on grain sizes and stirring times for Etna 2011 samples. The colours indicate different stirring times, expressed as seconds $\times 10^{3}$.

two grain size fractions are available. However, as a general behaviour, the release of elements is significantly greater for the finer grain size $(0.063 \mathrm{~mm})$ than for the $0.125 \mathrm{~mm}$ fraction (Figs. 7 and 8).

\subsection{Origin of $\mathrm{pH}$ changes}

The changes in $\mathrm{pH}$ values of leachates with respect to those of $\mathrm{mQ}$ and lake water relate to the release of $\mathrm{OH}^{-}$and $\mathrm{H}^{+}$ ions due to hydrolysis reactions of the salts dissolved from the ash surfaces (Sect. 6.1).
For Etna samples, the main hydrolysis reactions can be summarized as

$$
\begin{aligned}
& \mathrm{NaCl}+\mathrm{H}_{2} \mathrm{O}=\mathrm{Na}(\mathrm{OH})+\mathrm{HCl}=\mathrm{Na}^{+} \mathrm{OH}^{-}+\mathrm{H}^{+} \mathrm{Cl}^{-} \\
& (\mathrm{Na}, \mathrm{K}) \mathrm{F}+\mathrm{H}_{2} \mathrm{O}=(\mathrm{Na}, \mathrm{K})(\mathrm{OH})+\mathrm{HF}=(\mathrm{Na}, \mathrm{K})^{+} \\
& \mathrm{OH}^{-}+\left[\mathrm{H}^{+} \mathrm{F}^{-}\right]_{K} \\
& (\mathrm{Ca}, \mathrm{Mg}) \mathrm{SO}_{4}+\mathrm{H}_{2} \mathrm{O}=(\mathrm{Ca}, \mathrm{Mg})(\mathrm{OH})_{2}+\mathrm{H}_{2} \mathrm{SO}_{4}= \\
& {\left[(\mathrm{Ca}, \mathrm{Mg})^{2+} 2 \mathrm{OH}^{-}\right]_{K}+2 \mathrm{H}^{+} \mathrm{SO}_{4}^{2-}} \\
& (\mathrm{Mg}, \mathrm{Ca}) \mathrm{F}_{2}+\mathrm{H}_{2} \mathrm{O}=(\mathrm{Mg}, \mathrm{Ca})(\mathrm{OH})+2 \mathrm{HF}= \\
& {\left[(\mathrm{Mg}, \mathrm{Ca})^{2+} 2 \mathrm{OH}^{-}\right]_{K}+2\left[\mathrm{H}^{+} \mathrm{F}^{-}\right]_{K} .}
\end{aligned}
$$

Reaction (R1) exhibits a neutral $\mathrm{pH}$, producing a strong base and a strong acid that are totally dissociated in water. Reaction (R2) produces a strong base and a weak acid, which is 


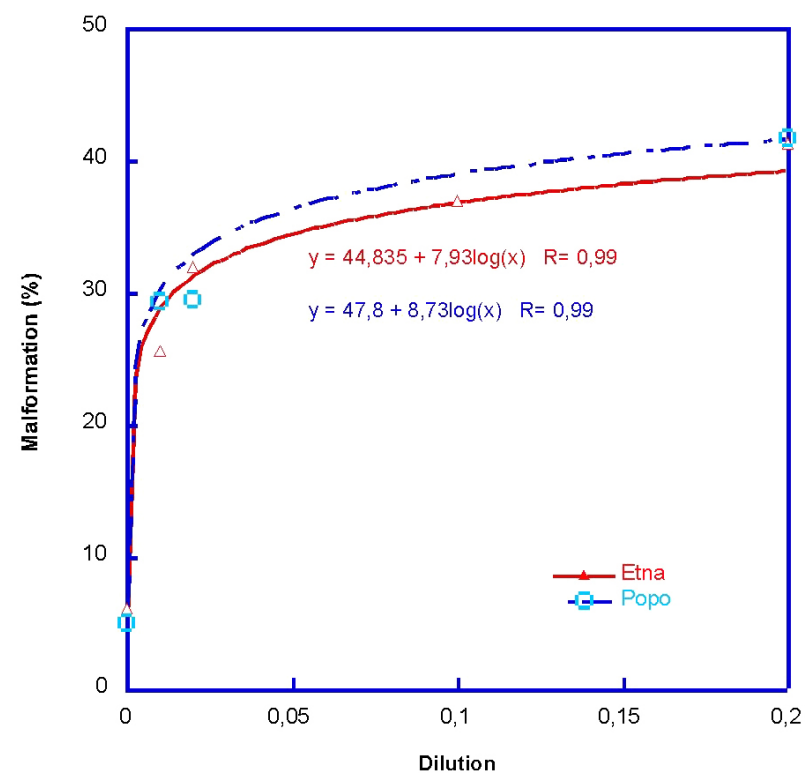

Figure 13. Malformation of embryos vs. dilution of ash leachates from Etna 2012 and Popocatépetl.

only partially dissociated to supply $\mathrm{H}^{+}$ions. It induces alkalinization of the leachates. Reaction (R3) produces a strong acid and a weak base, which induce acidification of the leachates. Reaction (R4) produces a weak acid and a weak base. Since the equilibrium constants are $K_{\mathrm{HF}}=6.6 \times 10^{-4}$ and $K_{\mathrm{Ca}(\mathrm{OH}) 2}=5.5 \times 10^{-6}$, the reaction induces slight alkalinization of the leachates. Being the sublimates on Etna ash dominated by $\mathrm{F}$ salts (Tables 1 and 2), the hydrolysis reactions are dominated by Reactions (R2) and (R4). This explains why the $\mathrm{pH}$ of Etna leachates is more alkaline with respect to the $\mathrm{mQ}$ water. The alkalinization is less effective when considering leachates in lake water, due to the presence of dissolved carbonates (Table 2) that buffers the hydrolysis reactions.

The same hydrolysis equations hold for the Popocatépetl samples, although they are dominated by dissociation of $(\mathrm{Ca}, \mathrm{Mg}) \mathrm{SO}_{4}$ salts (Tables 1 and 2). This explains why the Popocatépetl leachates are more acidic with respect to the $\mathrm{mQ}$ water (Fig. 5). The correlation of $\mathrm{pH}$ value with $\mathrm{SO}_{4}^{2-}$ is also testified by the higher acidification of $0.063 \mathrm{~mm}$ leachates with respect to the $0.125 \mathrm{~mm}$ ones (Fig. 5; Tables 1 and 2). The $\mathrm{pH}$ also varies very little when considering lake water for Popocatépetl samples, due to the buffering effect of already dissolved carbonates (Fig. 5; Tables 1 and 2).

\subsection{Drinkability of water leachates}

Drinking water quality is commonly regulated using a twotier system. Primary standards are legally enforceable limits set for contaminants posing a health risk (Table S7). Secondary standards are non-enforceable guideline values for contaminants which are not known to be a health risk but which make drinking water unacceptable to consumers because of aesthetic factors such as taste, colour, or odour (Table S7), or effects on the supply system such as staining or scale deposition) (Stewart et al., 2006).

Inspection of Etna and Popocatépetl mQ leachates shows that $\mathrm{F}^{-}$and $\mathrm{Mn}^{2+}$ elements are always well above the legal limits for drinking water (Table 1). Fe also exceeds the limits in most of the Etna samples and in all the Popocatépetl ones (Table 1). This makes the water dark in colour, bitter, with a metallic taste, and it can cause consumers to suffer with dental fluorosis and gastrointestinal diseases. The $\mathrm{SO}_{4}^{2-}$ also exceeds the limits in the Popocatépetl samples, adding a salty taste to the water and possibly causing consumers to suffer with diarrhoea.

The examination of leachates in lake water shows a similar behaviour of $\mathrm{mQ}$ water for $\mathrm{F}^{-}$, which exceeds the legal limits in all the samples. $\mathrm{Mn}^{2+}$ is in excess for all the Etna 2011 and Popocatépetl samples, but only in two samples of Etna 2012 (Table 2). Fe exceeds the limits for most of the analysed samples, while $\mathrm{SO}_{4}^{2-}$ is in excess in all the Popocatépetl samples (Table 2). Overall, the effects on water and consumers are the same as in $\mathrm{mQ}$ water.

The inspection of Tables 1, 3, and S4 highlights how the $\mathrm{F}^{-}$content is the most sensitive element for drinkability of leachates of Etna samples, its abundance is 6 to 14 (mQ water) or 1.5 to 10 (lake water) times the acceptable limit for potability (Tables 1,3 and S4). The $\mathrm{Mn}^{2+}$ and Fe are the most sensitive elements for Popocatépetl samples in mQ water (Tables 1, 3 and S4), with abundances between 10 and 50 times $\left(\mathrm{Mn}^{2+}\right)$ and 7 to 58 times ( $\left.\mathrm{Fe}\right)$ the legal limits. Considering lake water, the most sensitive element for Popocatépetl is $\mathrm{Mn}^{2+}$ (Tables 1, 3 and S4), its abundance is 3 to 50 times the legal limits for potability.

Taking into account the concentration of these elements in Etna and Popocatépetl leachates, it is possible to calculate the minimum weight of ash needed to exceed the legal limits of potability. As an example, for Etna 2011 samples in lake water, only $12 \mathrm{~kg}$ of ash per cubic metre of water are sufficient for making it undrinkable (using $\mathrm{F}^{-}$as benchmark). It means that, depending on the bulk density of the ash deposit, a thickness of $8 \mathrm{~mm} \mathrm{~m}^{-2}$ (bulk density of $1500 \mathrm{~kg} \mathrm{~m}^{-3}$ ) or $6 \mathrm{~mm} \mathrm{~m}^{-2}$ (bulk density of $2000 \mathrm{~kg} \mathrm{~m}^{-3}$ ) is sufficient for contaminating the water beyond the potability limits. The same exercise for Popocatépetl samples yields a mean weight of only $8 \mathrm{~kg}$ of ash per $\mathrm{m}^{3}$ (using $\mathrm{Mn}^{2+}$ as benchmark), which corresponds to $5 \mathrm{~mm} \mathrm{~m}^{-2}$ (bulk density of $1500 \mathrm{~kg} \mathrm{~m}^{-3}$ ) or $4 \mathrm{~mm} \mathrm{~m}^{-2}$ (bulk density of $2000 \mathrm{~kg} \mathrm{~m}^{-3}$ ). If applied to Lake Ohrid (water volume of ca. $5.5 \mathrm{~km}^{3}$ ), the required thickness of tephra deposited over the lake area is $12-15 \mathrm{~cm}$ for Etna compositions and 6-8 $\mathrm{cm}$ for Popocatépetl ones. Taking into account the thickness of past tephra layers recognized in Lake Ohrid succession (Sulpizio et al., 2010), the only deposit with similar thicknesses is the Campanian Ignimbrite-Y5 (Leicher et al., 2015). 
It is evident that to contaminate a big water reservoir like Lake Ohrid, an amount of volcanic ash only synonymous with super eruptions is necessary. Nevertheless, limited amounts of ash can impinge significantly on the availability of a primary resource like drinking water in many water reservoirs that are smaller than Lake Ohrid. This is an underestimated volcanic hazard, which can impact large areas and severely affect population if no preventive civil protection actions are taken in advance. Authorities have generally been unable to allay public fears because of a lack of supporting information on specific effects of volcanic ash on water supplies, including considerations such as the quantity of ash necessary to produce adverse effects, and the specific nature of contaminants that may pose a health risk to consumers or otherwise compromise the integrity of water supplies. A good example of this hazard is the potential contamination of water reservoirs of southern Italy, which are exposed to ash deposition in the case of renewal of explosive activity of Italian volcanoes (Sulpizio et al., 2014).

\subsection{Effects on living biota}

The deposition of volcanic ash on lake systems can impinge significantly on living biota. They can react in different ways, and show different resilience to external perturbation, as demonstrated for Lake Ohrid diatoms following the deposition of the Y5 tephra layer (Jovanovska et al., 2015). In order to evaluate the possible toxicity of released compounds on living biota, the ash leachates (from $\mathrm{mQ}$ water) were diluted in FETAX solution to obtain sequential dilutions from $1: 5$ to $1: 100 \mathrm{vol}$. / vol. This was planned to emulate natural conditions in which ash leachates are likely progressively diluted in the water basins. Under these experimental conditions both Etna and Popocatépetl leachates were mildly toxic to developing Xenopus laevis; and no significant differences exist between the toxic profiles of the two materials. Anyway, we outline that the higher content in F exhibited by the leachates from Etna may represent a potential teratogenic risk. Indeed, $\mathrm{F}^{-}$is known to be a powerful teratogen, as also demonstrated in Xenopus laevis (Goh and Neff, 2003). In this view, it may be useful to focus on the induced malformations more than on the deaths of embryos. It is evident that for both leachates the number of malformations is greater for low dilutions (Fig. 13), with a good logarithmic fit of the data. This means that even a small percentage of leachates (high dilutions) suddenly increases the malformations to above $20 \%$, which only augments to about $10 \%$ at higher concentrations (Fig. 13).

The changing $\mathrm{pH}$ also did not induce any big differences in teratogenesis. This allows us to consider the experimental results as being non-dependent on $\mathrm{pH}$ variations.

Although promising, these preliminary data on the ecotoxicity of Etna and Popocatépetl ash leachates necessitate more experimental evidence in order to fully understand the specific and comparative reactivity of the different leachates in terms of teratogenicity.

\section{Conclusions}

Leaching experiments on fresh ash samples from Etna 2011, Etna 2012, and Popocatépetl 2012 eruptions highlight some interesting indications about the behaviour of compound release in $\mathrm{mQ}$ and lake water. Surface analysis of unwashed ash demonstrates the presence of sublimated salts, and their leaching accounts for the observed composition of leachates in $\mathrm{mQ}$ water. The balance of leachates in lake water is more complex, due to the reaction of leached compounds with chemical elements dissolved in the lake water.

The hydrolysis reactions of the leached compounds also accounts for the observed $\mathrm{pH}$ variations in $\mathrm{mQ}$ and lake water, with Etna 2011-2012 samples that induce alkalinization and Popocatépetl samples that induce acidification of the original water samples.

Leaching experiments using different stirring times (from 30 min to 7 days) demonstrate the general poor dependence of compound release on time, with most of the release concentrated in the first hour of washing.

Grain size of ash particles has different and sometimes contrasting effects on release of compounds, with general inverse correlation for only $\mathrm{Na}^{+}, \mathrm{K}^{+}, \mathrm{Cl}^{-}, \mathrm{Ca}^{2+}, \mathrm{Mg}^{2+}$, $\mathrm{SO}_{4}^{2-}$, and $\mathrm{Mn}^{2+}$.

Saturation calculations highlight how Etna samples are always saturated for $\mathrm{F}$ and $\mathrm{Si}$ in $\mathrm{mQ}$ water, while leachates in lake water are saturated in $\mathrm{F}, \mathrm{Si}$, and carbonates, reflecting the contribution of elements already present in the solvent used. Popocatépetl samples show general saturation in some $\mathrm{Ca}, \mathrm{Si}, \mathrm{F}$, and $\mathrm{Fe}$ compounds in $\mathrm{mQ}$ water, similar to those calculated for lake water.

When compared with limits for potability imposed by European laws, it emerges that both $\mathrm{mQ}$ and lake leachates from Etna and Popocatépetl samples are classified as not allowed for human drinking due to the excess of $\mathrm{F}^{-}, \mathrm{Mn}^{2+}, \mathrm{Fe}$, and $\mathrm{SO}_{4}^{2-}$ (only Popocatépetl samples).

Etna 2012 and Popocatépetl leachates were used also for investigating the potential toxicity of living biota (Xenopus laevis). Experiments demonstrated that they are mildly toxic, and no significant differences exist between the toxic profiles of the two leachates. In particular, no significant increase of embryo deaths was observed, while even at high dilutions, the leachates produced more than $20 \%$ of malformed larvae.

\section{The Supplement related to this article is available online at doi:10.5194/bg-12-7087-2015-supplement.}


Acknowledgements. This research was carried out within the PRIN'09 project "Study of tephra layers in lacustrine sediments of the ICDP project "Scientific Collaboration on Past Speciation Conditions in Lake Ohrid (SCOPSCO)": evaluation of the environmental impact and contributions to chronology of sediments and to volcanic hazard assessment in distal areas" by Robert Sulpizio. Technician M. Pallara (DSTG-UNIBA) performed the XRF analyses. Thanks to Damiano Sarocchi (UASLP, Mexico) for providing the samples of Popocatépetl ash, and to Rosa Anna Corsaro (INGV Catania, Italy) for providing the Etna samples. Marco Cantù and Sara Meschiari are greatly acknowledged for their contribution to living biota experiments. F. A. Viehberg and an anonymous reviewer are acknowledged for the suggestions that improved the manuscript.

Edited by: B. Wagner

\section{References}

Araya, O., Wittwer, F., Villa, A., and Ducom, C.: Bovine fluorosis following volcanic activity in the southern Andes, Vet. Rec., 126, 641-642, 1990.

Araya, O., Wittwer, F., and Villa, A.: Evolution of fluoride concentrations in cattle and grass following a volcanic eruption, Vet. Hum. Toxicol., 35, 437-440, 1993.

Armienta, M. A., De la Cruz-Reyna, S., Morton, O., Cruz, O., and Ceniceros, N.: Chemical variations of tephra-fall deposit leachates for three eruptions from Popocatépetl volcano, J. Volcanol. Geoth. Res., 113, 61-80, 2002.

ASTM E1439-12: Standard Guide for Conducting the Frog Embryo Teratogenesis Assay-Xenopus (FETAX). Active Standard ASTM E1439, developed by Subcommittee E50.47, 1998.

Ayris, P. M. and Delmelle, P.: The immediate environmental effects of tephra emission, B. Volcanol., 74, 1905-1936, 2012.

Bacchetta, R., Mantecca, P., Andrioletti, M., Vismara, C., and Vailati, G.: Axial-skeletal defects caused by Carbaryl in Xenopus laevis embryos, Sci. Total Environ., 392, 110-118, 2008.

Baxter, P. and Ancia, A.: Human health and vulnerability in the Nyiragongo volcano crisis Democratic Republic of Congo 2002: Final report to the World Health Organisation, World Health Organnisation, 2002.

Blong, R.: Volcanic hazards, A sourcebook on the effects of eruptions, Academic Press, Sidney, 1984.

Boyd, P., Watson, A., Law, C., and Abraham, E.: A mesoscale phytoplankton bloom in the polar Southern Ocean stimulated by iron fertilization, Nature, 407, 695-702, 2000.

Chenon, P., Gauthier, L., Loubières, P., Séverac, A., and Delpoux, M.: Evaluation of the genotoxic and teratogenic potential of a municipal sludge and sludge-amended soil using the amphibian Xenopus laevis and the tobacco: Nicotiana tabacum L. var. xanthi Dulieu, Sci. Total Environ., 301, 139-150, 2003.

Clesceri, L. S., Greenberg, A. E., and Eaton, A. D.: Standard Methods for the examination of Water and Wastewater, 20th Edn., Public Health Assoc., Washington, DC, 1998.

Collins, C.: Contamination of water supplies and water courses, Appendix 2, Erupt. Ruapehu, New Zealand, 22 June 1969, DSIR Bull., 224, 1978.
Cronin, S. J. and Sharp, D. S.: Environmental impacts on health from continuous volcanic activity at Yasur (Tanna) and Ambrym, Vanuatu, Int. J. Environ. Health R., 12, 109-123, 2002.

Cronin, S. J., Neall, V., Lecointre, J., Hedley, M., and Loganathan, P.: Environmental hazards of fluoride in volcanic ash: a case study from Ruapehu volcano, New Zealand, J. Volcanol. Geoth. Res., 121, 271-291, 2003.

Cronin, S. J., Stewart, C., Zernack, A. V., Brenna, M., Procter, J. N., Pardo, N., Christenson, B., Wilson, T., Stewart, R. B., and Irwin, M.: Volcanic ash leachate compositions and assessment of health and agricultural hazards from 2012 hydrothermal eruptions, Tongariro, New Zealand, J. Volcanol. Geoth. Res., 286, 233-247, 2014.

Dawson, D. A.: Additive incidence on development malformation for Xenopus embryos exposed to a mixture of ten aliphatic carboxylic acids, Teratology, 44, 531-546, 1991.

Duggen, S., Croot, P., Schacht, U., and Hoffmann, L.: Subduction zone volcanic ash can fertilize the surface ocean and stimulate phytoplankton growth: Evidence from biogeochemical experiments and satellite data, Geophys. Res. Lett., 34, L01612, doi:10.1029/2006GL027522, 2007.

Flaathen, T. K. and Gìslason, S. R.: The effect of volcanic eruptions on the chemistry of surface waters: The 1991 and 2000 eruptions of Mt. Hekla, Iceland, J. Volcanol. Geoth. Res., 164, 293-316, 2007.

Fort, D. J., Rogers, R. I., Paul, R. R., Miller, M. F., Clark, P., Stover, E. L., Yoshioko, J., Quimby, F., Sower, S. A., Reed, K. I., Babbitt, K. J., and Rolland, R.: Effects of pond water, sediment and sediment extract samples from New Hampshire, USA on early Xenopus development and methamorphosis: comparison to native species, J. Appl. Toxicol., 21, 199-209, 2001.

Franzini, M., Leoni, L., and Saitta, M.: Revisione di una metodologia analitica per fluorescenza-X, basata sulla correzione completa degli effetti di matrice, Rend. Soc. Ital. Mineral. Petrol, 31, 365-378, 1975.

Frogner, P., Reynir Gíslason, S., and Óskarsson, N.: Fertilizing potential of volcanic ash in ocean surface water, Geology, 29, 487490, 2001.

Fruchter, J., Robertson, D., and Evans, J.: Mount St. Helens ash from the 18 May 1980 eruption: chemical, physical, mineralogical, and biological properties, Science, 209, 1116-1125, 1980.

Gíslason, S. R., Snorrason, Á., Kristmannsdóttir, H. K., Sveinbjörnsdóttir, Á. E., Torsander, P., Ólafsson, J., Castet, S., and Dupré, B.: Effects of volcanic eruptions on the $\mathrm{CO}_{2}$ content of the atmosphere and the oceans: The 1996 eruption and flood within the Vatnajökull Glacier, Iceland, Chem. Geol., 190, 181205, 2002.

Goh, E. H. and Neff, A. W.: Effects of fluoride on Xenopus embryo development, Food Chem. Toxicol., 41, 1501-1508, 2003.

Grattan, J. and Charman, D. J.: Non-climatic factors and the environmental impact of volcanic volatiles: implications of the Laki fissure eruption of AD 1783, The Holocene, 4, 101-106, 1994.

Gudmundsson, A. and Oskarsson, N.: The 1991 eruption of Hekla, Iceland, B. Volcanol., 54, 238-246, 1992.

Harvey, D.: Modern analytical chemistry, Mc Graw Hill, Boston, 816 pp., 2000.

Hayes, T. B., Falso, P., Gallipeau, S., and Stice, M.: The cause of global amphibian declines: a developmental endocrinologist's, J. Exp. Biol., 213, 921-933, 2010. 
Johnston, D. and Houghton, B.: Impacts of the 1945 and 1995-1996 Ruapehu eruptions, New Zealand: an example of increasing societal vulnerability, Geol. Soc. Am., 112, 720-726, 2000.

Jones, M. T. and Gìslason, S. R.: Rapid releases of metal salts and nutrients following the deposition of volcanic ash into aqueous environments, Geochim. Cosmochim. Ac., 72, 3661-3680, 2008.

Jovanovska, E., Cvetkoska, A., Hauffe, T., Levkov, Z., Wagner, B., Sulpizio, R., Francke, A., Albrecht, C., and Wilke, T.: Differential resilience of ancient sister lakes Ohrid and Prespa to environmental disturbances during the Late Pleistocene, Biogeosciences Discuss., 12, 16049-16079, doi:10.5194/bgd-1216049-2015, 2015.

Leicher, N., Zanchetta, G., Sulpizio, R., Giaccio, B., Wagner, B., Nomade, S., Francke, A., and Del Carlo, P.: First tephrostratigraphic results of the DEEP site record from Lake Ohrid, Macedonia, Biogeosciences Discuss., 12, 15411-15460, doi:10.5194/bgd-12-15411-2015, 2015.

Leoni, L. and Saitta, M.: X-ray fluorescence analysis of 29 trace elements in rock and mineral standards, Rend. Soc. Ital. Mineral. Petrol, 32, 497-510, 1976.

Mantecca, P., Gualtieri, M., Andrioletti, M., Bacchetta, R., Vismara, C., Vailati, G., and Camatini, M.: Tire debris organic extract affects Xenopus development, Environ. Int., 33, 642-648, 2007.

Marianelli, P. and Sbrana, A.: Risultati di misure di standard di minerali e di vetri naturali in microanalisi a dispersione di energia, Atti Soc. Tosc. Sc. Nat. Resid. Pisa, Mem. Serie A, 105, 57-63, 1998.

Martin, R. S., Watt, S. F. L., Pyle, D. M., Mather, T. A., Matthews, N. E., Georg, R. B., Day, J. A., Fairhead, T., Witt, M. L. I., and Quayle, B. M.: Environmental effects of ashfall in Argentina from the 2008 Chaitén volcanic eruption, J. Volcanol. Geoth. Res., 184, 462-472, 2009.

Oppenheimer, C., Barclay, D. M., and Pyle, J.: Volcanic Degassing, GSL Special Publications, London, 213, 2003.

Óskarsson, N.: The interaction between volcanic gases and tephra: Fluorine adhering to tephra of the 1970 hekla eruption, J. Volcanol. Geoth. Res., 8, 251-266, 1980.

Qu, W. J., Zhang, X. Y., Arimoto, R., Wang, D., Wang, Y. Q., Yan, L. W., and Li, Y.: Chemical composition of the background aerosol at two sites in southwestern and northwestern China: potential influences of regional transport, Tellus B, 60, 657-673, 2008.

Rose, W., Bonis, J., and Stoiber, S.: Studies of volcanic ash from two recent Central American eruptions, B. Volcanol., 37, 338364, 1973.

Rubin, C., Noji, E., and Seligman, P.: Evaluating a fluorosis hazard after a volcanic eruption, Arch. Environ. Health, 49, 395-401, 1994.

Ruggieri, F., Saavedra, J., Fernandez-Turiel, J. L., Gimeno, D., and Garcia-Valles, M.: Environmental geochemistry of ancient volcanic ashes, J. Hazard. Mater., 183, 353-365, 2010.

Shanks, D.: Clinical implications of volcanic eruptions on livestock: case studies following the 1995 and 1996 eruptions of Mt. Ruapehu, Proc. from 27th Semin. Soc. Sheep Beef Cattle Vet. NZVA Conf. Week 1997, 29 June to 4 July 1997, Wairakei Resort Hotel, New Zealand, 1997.
Smith, M. and White, M.: Observations on lakes near Mount St Helens: phytoplankton, Arch. Hydrobiol., 104, 345-362, 1985.

Smithsonian Institution: Soufriere Hills, Bull. Glob. Volcanism Netw., 22, 2-4, 1997.

Smithsonian Institution: Copahue, Bull. Glob. Volcanism Netw., 25, 7-10, 2000.

Stefánsson, K. and Sigurjónsson, J.: Temporary increase in fluorine content of water following the eruption: The eruption of Hekla, 1947-1948, Soc. Sci. Islandia, 2, 1-13, 1957.

Steingrímsson, J. and Kunz, K.: Fires of the earth: the Laki eruption, 1783-1784, Univ. Icel. Pr., 1998.

Stewart, C., Johnston, D. M., Leonard, G. S., Horwell, C. J., Thordarson, T., and Cronin, S. J.: Contamination of water supplies by volcanic ashfall: A literature review and simple impact modelling, J. Volcanol. Geoth. Res., 158, 296-306, 2006.

Sulpizio, R., Zanchetta, G., D’Orazio, M., Vogel, H., and Wagner, B.: Tephrostratigraphy and tephrochronology of lakes Ohrid and Prespa, Balkans, Biogeosciences, 7, 3273-3288, doi:10.5194/bg7-3273-2010, 2010.

Sulpizio, R., Zanchetta, G., Caron, B., Dellino, P., Mele, D., Giaccio, B., Insinga, D., Paterne, M., Siani, G., Costa, A., Macedonio, G., and Santacroce, R.: Volcanic ash hazard in the Central Mediterranean assessed from geological data, B. Volcanol., 76, $1-8,2014$.

Thorarinsson, S.: The Lakagígar eruption of 1783, B. Volcanol., 33, 910-929, 1969.

Thorarinsson, S. and Sigvaldason, G.: The Hekla eruption of 1970, B. Volcanol., 36, 269-288, 1972.

Uematsu, M., Toratani, M., Kajino, M., Narita, Y., Senga, Y., and Kimoto, T.: Enhancement of primary productivity in the western North Pacific caused by the eruption of the Miyake-jima Volcano, Geophys. Res. Lett., 31, L06106, doi:10.1029/2003GL018790, 2004.

Wardman, J. B., Wilson, T. M., Bodger, P. S., Cole, J. W., and Johnston, D. M.: Investigating the electrical conductivity of volcanic ash and its effect on HV power systems, Phys. Chem. Earth, 4546, 128-145, 2012.

Weniger, B. and Blaser, M.: An outbreak of waterborne giardiasis associated with heavy water runoff due to warm weather and volcanic ashfall, Am. J. Public Health, 73, 868-872, 1983.

Wilcox, R. and Coats, R.: Some effects of recent volcanic ash falls with especial reference to Alaska, US Gov. Print. Off., Washington, DC, 1959.

Wilson, T. M., Stewart, C., Sword-Daniels, V., Leonard, G. S., Johnston, D. M., Cole, J. W., Wardman, J., Wilson, G., and Barnard, S.T.: Volcanic ash impacts on critical infrastructure, Phys. Chem. Earth, 45-46, 5-23, 2012.

Witham, C. S., Oppenheimer, C., and Horwell, C. J.: Volcanic ashleachates: a review and recommendations for sampling methods, J. Volcanol. Geoth. Res., 141, 299-326, 2005. 